\title{
Formation and evolution of glauconite in the Demerara Contourite depositional system related to NADW circulation changes during late Quaternary (French Guiana)
}

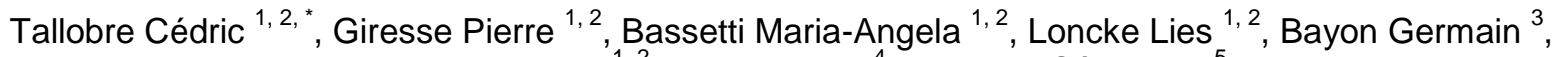 \\ Buscail Roselyne ${ }^{1,2}$, Tudryn Alina ${ }^{4}$, Zaragosi Sébastien ${ }^{5}$
}

${ }^{1}$ Univ. Perpignan Via Domitia, Centre de Formation et de Recherche sur les Environnements Méditerranéens (CEFREM), UMR 5110, 52 Avenue Paul Alduy, 66860, Perpignan, France

${ }^{2}$ CNRS, Centre de Formation et de Recherche sur les Environnements Méditerranéens (CEFREM), UMR 5110, 52 Avenue Paul Alduy, 66860, Perpignan, France

${ }^{3}$ IFREMER, Unité de Recherche Géosciences Marines, 29280, Plouzané, France

${ }^{4}$ GEOPS, Univ. Paris-Sud, CNRS, Université Paris-Saclay, Rue du Belvédère, Bât. 504-509, 91405, Orsay, France

${ }^{5}$ Université de Bordeaux, Environnements et Paléoenvironnements Océaniques et Continentaux, UMR CNRS 5805 EPOC, Allée Geoffroy Saint-Hilaire, CS 50023 - 33615, Pessac cedex, France

* Corresponding author : Cédric Tallobre, email address : cedric.tallobre@univ-perp.fr

\begin{abstract}
:
The Demerara Plateau is a marginal plateau which forms a bathymetric relief on the sea floor. Here, contourite deposits have been studied in detail, following the recent discovery of contourite sequences likely related to the bottom currents and linked both to contour current and peculiar sea-floor morphology. A chronostratigraphic framework, based on $\delta 180$ relative variations and palaeomagnetic events in sediment cores allows correlating sediment processes to current intensity changes and major climate phases (glacial or interglacial). The studied sediments are enriched in glauconitic grains. In addition, the glauconite mineralogical maturity can easily correlate to low sedimentation rate and slightly energetic bottom currents on the seafloor. Based on these data and using the glauconitic authigenic mineral as proxy for inferring the degree of winnowing at the sediment-water interface, we might put forward the hypothesis that the intensity of NADW is higher during the glacial stages and lower during interglacial periods.
\end{abstract}

\section{Highlights}

- A contourite depositional system is present on the Demerara Plateau. The winnowing effect induced by bottom current allows formation of authigenic mineral. The glauconitic content and maturity of glauconitic grains are indicator of the current intensity.

Keywords : marginal plateau, contourite, glauconite, Demerara Plateau 
34 Contourites are sediments deposited or reworked by the action of a persistent bottom

35 current. The identification of sedimentary structures on the seafloor induced by current 36 activity introduces the concept of contourites by Heezen (1959), Heezen and Johnson (1963),

37 and Heezen and Hollister (1964). The presence of contourites is marked by a set of different 38 depositional and erosional structures at different scales. All of these structures and their 39 evolution compose a 'Contourite Depositional System' or CDS (Rebesco and Camerlenghi, 40 2008).

41 Contourites are generally characterized by a graded and often bioturbated sedimentary 42 sequence (Faugères et al., 1984; Gonthier et al., 1984; Stow et al., 2002; Stow and Faugères, 43 2008a; Rebesco et al., 2014; Shanmugam, 2016). The ideal sequence was established by 44 Faugères et al. (1984) and Gonthier et al. (1984) and completed by Stow and Faugères 45 (2008a). The alternation of positive and inverse grading sequences, composed of 5 units from $46 \mathrm{C} 1$ to $\mathrm{C} 5$, might record velocity current variations through time. The ideal contourite 47 sequence is composed of the $\mathrm{C} 1$ to $\mathrm{C} 5$ units:

48 - Unit $\mathrm{C} 1$ is the mud unit rich in clays, in fine silt without lamination and rich in 49 bioturbation structures. This unit corresponds to a low current velocity;

50 - Unit C2, mottled silt and mud, is coarser than $\mathrm{C} 1$ with silty lenses and bioturbation; 
- Unit C3 is characterized by coarsening upward sediment grain size that increases Bioturbation might be strong and can destroy laminations. Erosional surfaces are possible, linked to high bottom current activity;

- Unit C4: mottled silt and mud, with silty lenses and bioturbation

- Unit C5: mud unit rich in clays and in fine silt without lamination and rich in bioturbation structures, and this unit correspond to a low current velocity.

$\mathrm{C} 1$ to $\mathrm{C} 3$ corresponds to the positive graded sequence generated by increasing current intensity and C3 to C5 to the negative (inverse) graded sequence following the decrease of current intensity (Faugères et al., 1984; Gonthier et al., 1984; Stow and Faugères, 2008b). The sedimentation can sometimes be affected by diagenetic processes with the formation of authigenic concretions such as nodules and/or encrustations of manganese, as well glauconitic grains, as reported by several authors (Bahk et al., 2001; Giresse and Wiewióra, 2001; Lee et al., 2004; Bahk et al., 2005; Stow and Faugères, 2008a; Faugères and Mulder, 2011).

According to the existing literature (Banerjee et al., 2016), the formation of glauconitic grains is mainly associated to low sedimentation rate on the continental shelf whereas the glauconitisation process in deep marine environments is poorly known. Some authors relate the low sediment accumulation rates to winnowing effect at the sediment-water interface (Chafetz and Reid, 2000; Giresse and Wiewióra, 2001; Wiewióra et al., 2001; Giresse, 2008). Glaucony is a greenish grain which belongs to the glauconite mineral family, and which forms inside shells (often foraminifer tests) or pellets or biotite sheets (McRae, 1972; Odin, 1988; Giresse and Wiewióra, 2001; Wiewióra et al., 2001; Giresse, 2008; Banerjee et al., 2016).

One of the objectives of the IGUANES oceanographic cruise (2013) on the Demerara Plateau (French Guiana) was to shed lights on the sedimentary processes at the origin of the observed depositional sequences, possibly in relation with climate oscillations. This site has been found to host a CDS, yielding sediments rich in authigenic grains of glaucony. In this 
work, a major element analysis of the green glauconitic grains has been carried out with the objective of understanding the possible role of bottom current velocity in the early diagenetic processes forming glaucony and, consequently, to use this tool as a proxy for bottom current intensity.

\section{Background of the study area}

The Atlantic margin of the South American continent is affected by extended contouritic processes in several places, such as along the Argentina or Brazil margins (Viana et al., 1998; Faugères et al., 2002; Hernández-Molina et al., 2009; Rebesco et al., 2014; Shanmugam, 2016). The Demerara plateau, which forms a seafloor salient prolonging the continental shelf down to $~ 3400 \mathrm{~m}$ depth (Fig.1-2), has been described as a site where bottom currents might have strong control over the shape of the seafloor. The morphology of this plateau is thought to be at the origin of the contourite deposits, since it might favour the acceleration of bottom currents (Loncke et al., 2016; Tallobre et al., 2016).

\section{Oceanographic setting}

The Demerara Plateau is located at latitude N $7^{\circ} 30$ between the Equator and the Tropic of Cancer (Fig.1), climatically under the influence of the InterTropical Convergence Zone (ITCZ), whose northern limit is at $\mathrm{N} 10^{\circ}$ during the boreal summer (Müller-Karger et al., 1989; Arz et al., 1999; López-Otálvaro et al., 2009). The main water masses controlling the hydrodynamism in this area are (Reid, 1989; Peterson and Stramma, 1991; Tsuchiya et al., 1994; Stramma and Schott, 1999):

- The surface water with the Tropical Surface Water (TSW) and the North Tropical Gyre

- The Antarctic Intermediate Water (AAIW) formed in the Southern Ocean 
- The deep water masses composed by the North Atlantic Deep Water (NADW) derived from the North Atlantic and Arctic Seas, and the Antarctic Bottom Water (AABW) formed around Antarctica (Fig.1).

\section{Geological setting}

The Demerara Plateau is a marginal plateau (Loncke et al., 2016; Mercier de Lépinay et al., 2016) located at the junction between the Central and Equatorial Atlantic Oceans (Fig.1). It is the conjugate margin of the Guinean Plateau. These two plateaus were initially separated by a transform fault. The marginal plateau of Demerara forms an indentation, an overhang on the seafloor that is $160 \mathrm{~km}$ wide and $350 \mathrm{~km}$ long (Fig.1), ranging from water depths of 200 to $3800 \mathrm{~m}$ (Fig.2).

This bathymetric relief hosts two main types of sedimentation along its outer edge: mass transport deposit and contourites (Hurley et al., 1967; Ingram, 2006; Loncke et al., 2009; Gaullier et al., 2010; Pattier et al., 2013; Loncke et al., 2016). The main mass transport deposit (MTD) accumulations occurred between the Oligocene and the Pleistocene (Pattier et al., 2013; Pattier et al., 2015). The associated slope failure trace is still imprinted on the present-day bathymetry, forming a linear slope failure headscarp over $150 \mathrm{~km}$ in length that parallels the distal transform marginal plateau boundary (Loncke et al., 2016).

The impact of the bottom current on the construction and evolution of the CDS along the Demerara Plateau is highlighted by recent studies (Loncke et al., 2009; Pattier et al., 2015; Loncke et al., 2016; Tallobre et al., 2016). The presence of the marginal plateau, an overhang on the seafloor, enables the intensification of the NADW (NW-SE) and promotes the formation of contourites on the Demerara plateau. Many erosional features, such as NW-SE oriented comet marks, have been identified and attest of the impact of bottom current on the seafloor structures. 


\section{Climate general features of the study area}

The global climate oscillations are known through the study of various marine $\delta^{18} \mathrm{O}$ record 2013; Menviel et al., 2014). Particularly, during MIS 2 and MIS 4 glacial conditions, the vegetation in the Guiana basin was characterized by savanna-type ecosystems (van der were stronger generating a southward migration of the ITCZ and inducing drier climate

139 Orinoco was more important during the interglacial, as consequence of the ITCZ northward 140 migration, when the Amazon basin turned into drier conditions.

\section{Materials and methods}

143 Three cores collected during the IGUANES cruise (2013, http://dx.doi.org/10.17600/13010030)

144 are studied in this work (Fig. 2):

- IG-KSF-05 (at $08^{\circ} 02.80 \mathrm{~N}$ and $052^{\circ} 23.19 \mathrm{~W}, 3014 \mathrm{~m}$ water depth, $7 \mathrm{~m}$ in length), 
deposition. It is made of homogeneous grey-greenish mud with interbedded sandy intervals (Fig.3). located in the moat that follows the headscarp slope failure, where the current influence is the strongest. This core is composed of grey-greenish mud containing scattered sandy lenses (Fig.4).

- IG-KSF-15 (at $07^{\circ} 27.98 \mathrm{~N}$ and $052^{\circ} 19.76 \mathrm{~W}, 2578 \mathrm{~m}$ of water depth, $5 \mathrm{~m}$ in length), located in the moat same as IG-KSF-11 but located inside a comet mark shape depression. The core made of grey-greenish mud rich in green sandy grains with several carbonated-rich intervals interbedded (Fig.5).

\section{Sediment analyses}

Visual descriptions on split cores were performed to identify sedimentary facies. The sandy fraction $(>63 \mu \mathrm{m})$ was separated by wet sieving for observation under the microscope in order to quantitative evaluating the sand composition.

161 Grain-size analyses were performed on bulk sediment using a Malvern Mastersizer 3000

were generated: in bulk and carbonate-free sediment fractions. All samples (bulk sediment and carbonate-free) were placed in a solution of sodium metaphosphate $\left(\mathrm{NaPO}_{3}\right)$ at $1.5 \mathrm{~g} / \mathrm{L}$ to deflocculate clay minerals. The distribution of size particles are used as an indicator of the winnowing effect (McCave et al., 1995; McCave and Hall, 2006).

168 Semi-quantitative geochemical analyses (element count rates) were performed along core IG-KSF-11 with an Avaatech X-Ray Fluorescence (XRF) core scanner (IFREMER, Brest) operated at both $10 \mathrm{kV}$ and $30 \mathrm{kV}$ and with a $1 \mathrm{~cm}$ sampling interval. In this study, Ca has

171 been used to provide information about the biogenic components. 
172

173

174

175

176

177

178

179

180

181

182

183

184

185

186

187

188

189

190

191

192

193

194

195

196

\section{Glauconite study; quantification and analyses}

The quantification of glauconitic grains was carried out on the sandy fraction every $10 \mathrm{~cm}$ in cores IG-KSF-11 (Fig. 4) and IG-KSF-15 (Fig. 5). The glauconitic grains were isolated under the microscope. Those were weighed and the weight was normalized with respect to 1) the sandy fraction and 2) the bulk sediment and then expressed as a percentage (\%). The glauconitic grains were classified into three colour categories: yellowish-green, green, and dark green (visual estimation), the last one being sub-divided into dark and very dark green Representative samples were selected on core IG-KSF-11 for SEM observation, using a SEM HITACHI S-4500. These samples (104 grains) were collected at different intervals on IGKSF-11: $0 \mathrm{~cm}, 50 \mathrm{~cm}, 270 \mathrm{~cm}, 300 \mathrm{~cm}, 450 \mathrm{~cm}, 460 \mathrm{~cm}$ and $590 \mathrm{~cm}$. Quantitative elementary analyses were performed using a SEM-EDS system. Two measurements were carried out at the surface of each grain. These samples were collected at different intervals on IG-KSF-11: $50 \mathrm{~cm}, 270 \mathrm{~cm}, 300 \mathrm{~cm}, 450 \mathrm{~cm}, 460 \mathrm{~cm}$ and $590 \mathrm{~cm}$. To complete this study, 9 additional samples on the 0 and $100 \mathrm{~cm}$ interval on IG-KSF-11 and one on the top of IG-KSF-15) were analysed for X-ray diffraction (Philips) on the $<2 \mu \mathrm{m}$ fraction for clay minerals.

Four thin sections from indurated sediment were obtained in the IG-KSF-11, following the method described by Zaragosi et al. (2006). The selected intervals are: $20-40 \mathrm{~cm}$; $337-$ $367 \mathrm{~cm} ; 449-479 \mathrm{~cm} ; 580-600 \mathrm{~cm}$ (glauconite rich horizons). Thin sections have been observed under transmitted polarizing microscope for micro-facies description.

\section{Chronostratigraphy}

Radiocarbon dates in different cores (IG-KSF-05 and IG-KSF-11) were obtained by Accelerator Mass Spectrometry (AMS) at the Poznań Radiocarbon Laboratory, using monospecific assemblages of well-preserved planktic foraminifer Globigerinoides $s p$. Measured ages were converted to calendar years using Calib 7.0.4 with the Marine 09 calibration curve (Reimer et al., 2013). 
Oxygen stable isotope ratios were measured on samples from cores IG-KSF-11 and IG-

198 KSF-05 using a $5 \mathrm{~cm}$ sampling step. These measurements were carried out on benthic (Uvigerina mediterranea) and planktonic (Globigerinoides ruber and Globigerinoides sp.) (Kiel, Germany).

Magnetic parameters allow an identification of the magnetic field at the time of sediment.

203 NRM and isothermal remanent magnetization (IRM) measurements were made on cores IGKSF-05 and IG-KSF-11, on U-channels (at $2 \mathrm{~cm}$ intervals) with a horizontal $2 \mathrm{G}$ Entreprises pass-through cryogenic magnetometer. NRM was demagnetized with an AF up to $80 \mathrm{mT}$ using the in-line mounted alternating field (AF) demagnetizer. IRM was introduced in $1 \mathrm{~T}$ and $-0.3 \mathrm{~T}$ fields, and the S-ratio $\left(\mathrm{IRM}_{-0.3 \mathrm{~T}} / \mathrm{IRM}_{1 \mathrm{~T}}\right)$ was calculated.

\section{E. Results}

\section{Chronostratigraphy}

A multiproxy study was necessary to establish a chronostratigraphic framework. The steps followed for establishing a depth-age profile are described below, together with comments about the difficulties encountered.

\section{Radiocarbon data}

\section{IG-KSF11:}

In core IG-KSF-11 from 0 to $190 \mathrm{~cm}$ depth the ${ }^{14} \mathrm{C}$ ages range from $14 \mathrm{kyr}$ BP to $50 \mathrm{kyr}$ BP (Table 1), without any anomaly. The sediment accumulation rates calculated for this interval are:

- $\quad 0$ - $60 \mathrm{cm:} 2.7 \mathrm{~cm} / \mathrm{kyr}$

- $\quad 60-130 \mathrm{~cm}: 23 \mathrm{~cm} / \mathrm{kyr}$

- 130 - $190 \mathrm{~cm}: 5.5 \mathrm{~cm} / \mathrm{kyr}$. 
The first stratigraphically incoherent age occurs at $313 \mathrm{~cm}$ with $43 \mathrm{kyr}$ cal BP, followed by the $530 \mathrm{~cm}$ level, where two different ages are obtained (49 kyr BP and $26 \mathrm{kyr} \mathrm{BP}$ ). The second measurement was performed on bulk sediment. Unfortunately, this material does not contain enough organic matter for accurate dating. Other stratigraphically incoherent ages are found at the bottom of the core at $582 \mathrm{~cm}(39 \mathrm{kyr}$ BP) and $600 \mathrm{~cm}(28$ and $35 \mathrm{kyr}$ $\mathrm{BP})$. The base of the core $(600 \mathrm{~cm})$ was measured twice and the resulting ages are largely different with a gap of $7 \mathrm{kyr}$.

\section{$\underline{\text { IG-KSF-05: }}$}

The upper part of core IG-KSF-05 $(0 \mathrm{~cm})$ is dated at $5.6 \mathrm{kyr}$ BP. The ages obtained deeper range from $44 \mathrm{kyr}$ to $5.6 \mathrm{kyr}$ (table 1) and give the following sediment accumulation rates:

- $\quad 0-29 \mathrm{~cm}: 2.4 \mathrm{~cm} / \mathrm{kyr}$

Some stratigraphic incoherencies are also present in this deeper part of the core (Table 1):

Thus, the stratigraphic incoherence and the strong difference in the sedimentation rates highlight the anomaly of dating, especially in the lower part of the two cores.

\section{Stable isotopes and chronostratigraphy}

Tie points have been identified comparing the relative oxygen isotope variations in the two

240 cores studied in this work (Fig.6, table 2), in order to correlate them with Marine Isotope 241 Stages (MIS).

242 The regional curves used here as references are (Fig.6): water depth of $1233 \mathrm{~m}$ and published in López-Otálvaro et al. (2009); 
2) the Atlantic Ocean compilation from Lisiecki and Raymo (2005), (2009);

3) oxygen isotope ratios from core GeoB 3104 from a water depth of $767 \mathrm{~m}$ in the North Brazilian margin (Arz et al., 1998).

MIS 1 (0-11.7 kyr): The core-tops of IG-KSF-11 and IG-KSF-05 (0 cm) do not correspond to modern ages, possibly because the upper part of the sediment column was lost during coring. A rapid increase of $\delta^{18} \mathrm{O}$ values is observed at $10 \mathrm{~cm}$ depth in core IG-KSF-11 and at $18 \mathrm{~cm}$ depth in core IG-KSF-05, which can correlate with the beginning of MIS 1.

- $\quad$ MIS 2 (11.7-24.1 kyr): Between 10 and $43 \mathrm{~cm}$ with a sedimentary accumulation rate of $2.7 \mathrm{~cm} / 10^{3} \mathrm{yr}$ in core IG-KSF-11 and 18 and $139 \mathrm{~cm}$ with a rate of $9.2 \mathrm{~cm} / 10^{3} \mathrm{yr}$ in core IG-KSF-05, relatively high positive $\delta^{18} \mathrm{O}$ values are thought to correspond to the MIS 2 cold stage. The low resolution of the isotope measurements does not allow us to precisely identify the glacial maximum, but the correlation with Arz et al. (1998) isotope curve, suggests that the LGM could be positioned at $20 \mathrm{~cm}$ depth in IG-KSF11 and at $35 \mathrm{~cm}$ depth in IG-KSF-05 (Fig.6);

- MIS 3 (24.1-58.9 kyr): The interval comprised between 43 and $80 \mathrm{~cm}$ in IG-KSF-11 $\left(1 \mathrm{~cm} / 10^{3} \mathrm{yr}\right)$ and between 139 and $451 \mathrm{~cm}$ in IG-KSF-05 $\left(8.7 \mathrm{~cm} / 10^{3} \mathrm{yr}\right)$ is tentatively assigned to MIS 3. However, its features cannot be directly compared to the global curves (Fig.6), mainly because of the occurrence of relatively negative values obtained in planktonic and benthic foraminifera in both cores (Fig.6). These oscillations are not evident at the global scale but are nonetheless observed regionally, as illustrated in López-Otálvaro et al. (2009);

MIS 4 (58.9-74 kyr): This (moderate) glacial stage is located in the $80-150 \mathrm{~cm}$ interval in core IG-KSF-11 $\left(4.6 \mathrm{~cm} / 10^{3} \mathrm{yr}\right)$ and in the $451-590 \mathrm{~cm}$ interval in core IGKSF-05 $\left(9.2 \mathrm{~cm} / 10^{3} \mathrm{yr}\right)$, based on the relative $\delta^{18} \mathrm{O}$ variations compared to MIS 3 
(Fig.6). The pattern of isotope ratio values is considered coherent and comparable with the global temperature trends;

- MIS 5 (74-130 kyr): The interval between 150 and $267 \mathrm{~cm}$ in IG-KSF-11 and 590 and $694 \mathrm{~cm}$ in IG-KSF-05 is assigned to MIS 5. The MIS 5 is subdivided into five substages (MIS 5.1 to MIS 5.5) that are recorded in many areas of the ocean (Shackleton et al., 2003) where the MIS 5.5 consists in the most prominent temperature rise (Fig.6). In core IG-KSF-11, two intervals show considerably negative $\delta^{18} \mathrm{O}$ values (at 160-200 cm depth and 235-365 cm depth, Fig.6) that could possibly match the MIS 5.1 and 5.3. Thus, the basal prominent peak would be missing. The reason why it is lacking is not clear, but a non-depositional or even an erosional episode is possible.

- MIS 6 (130-189.6 kyr) and MIS 7 (189.6-244 kyr)?: Below MIS 5, the correlation becomes really uncertain. A possible assignment of the interval comprised between 267 and $371 \mathrm{~cm}$ in core IG-KSF-11 to MIS 6 is proposed, since the relatively positive $\delta^{18} \mathrm{O}$ values might be consistent with a glacial stage (Fig.6), but there is no other proxy that could confirm this hypothesis. Even more difficult is the interpretation of the interval below $380 \mathrm{~cm}$ depth in core IG-KSF-11 (Fig.6) since it is possibly affected by heavy reworking. In an optimistic view, it could be possible to consider that the interval comprised between 371 and $422 \mathrm{~cm}$ depth might belong to MIS 7, but with no certitude. On the other hand, below $430 \mathrm{~cm}$ depth, the sediment is fully reworked. The question, which remains open in this work, is when this reworking took place, either during the glacial stage (MIS 8), the interglacial (MIS 7), or later.

\section{Palaeomagnetism}

As shown by Bleil and Von Dobeneck (1999), the natural remanent magnetization (NRM) 
detrital minerals such as magnetite and hematite become aligned by the geomagnetic field as they fall through the water and become part of the sediment on the bottom of the sea; it is the detrital remanent magnetization (DRM) that often contributes predominately to the NRM in such marine sediments.

In the cores IG-KSF-11 and IG-KSF-05, the NRM decrease during the demagnetisation and the S-ratio values varying between 0.9 and 0.8 indicate that the magnetic fraction of the sediment is dominated by minerals of low coercivity such as magnetite, with minor amounts of higher coercivity minerals - hematite or goethite (Tudryn et al., 2010). In the bottom (600 $450 \mathrm{~cm} \mathrm{depth)}$ of the core IG-KSF-11, slightly lower S-ratio values (0.7 - 0.8) indicate increased contents of the hematite and/or goethite. NRM shows stability in direction and low inclination values, except in the bottom of the core IG-KSF-11 (Fig. 4) and the top of IGKSF-05 (Fig. 3). On the top of the core IG-KSF-05, an important variation in declination and inclination is recorded around the transition between MIS $1(0-18 \mathrm{~cm})$ and MIS $2(25-139 \mathrm{~cm})$ as identified through $\delta^{18} \mathrm{O}$ record (above); it likely corresponds to the Gothenburg Geomagnetic Polarity Excursion at 12.5 kyr (Mörner, 1977; Barbetti et al., 1980; Mörner, 1986), described between 12.5 and $13.5 \mathrm{kyr}$ in European and Cameroon lakes (Smith and Creer, 1986; Thouveny and Williamson, 1988; Maley et al., 1990). The Laschamp event, around 40 kyr (Bonhommet and Babkine, 1967; Guillou et al., 2004; Plenier et al., 2007), and the Blake event, around 119 kyr (Lund et al.; Smith and Foster, 1969; Gibbard and Cohen, 2008), seem to be absent or not identifiable in the studied successions. Nonetheless, the stability of magnetic parameters suggests that the sediment was not affected by postdepositional reworking, except for the basis of IG-KSF-11 and probably the top of IG-KSF05. 


\section{Grain size analysis}

In the core IG-KSF-11 (Fig.4), the average clay content is $20 \%$ of the total sediment, 320 while the fine silt-size fractions account for between 40 and $60 \%$ and hence constitute the 321 dominant fraction. Coarse silt and sand correlate to Ca relative content suggesting that this 322 relatively coarse fraction is made of biogenic carbonates, relatively abundant during estimated 323 ice periods (MIS 2-4-6; Fig.4).

324 The free carbonate $\overline{\mathrm{SS}}$ varies between $15 \mu \mathrm{m}$ and $30 \mu \mathrm{m}$ (Fig.4). With respect to the bulk 325 sediment grain-size plot, the $\overline{\mathrm{SS}}$ is high between $420-600 \mathrm{~cm}$ and the bottom of the core. The 326 values increase during the ice period MIS $6(267-371 \mathrm{~cm})$ and decrease to relatively low 327 values during MIS $5(150-267 \mathrm{~cm})$. Some higher values correspond to the $200-230 \mathrm{~cm}$ 328 interval and are associated with an increase in isotopic values. The $\overline{\mathrm{SS}}$ becomes high from MIS 4 and through the 'weak' MIS 3 interglacial (Fig.4).

\section{Facies}

\section{Analysis}

Seven sedimentary facies have been identified after visual description of all cores 333 (Tallobre, 2017), combined with observations of thin sections on core IG-KSF-11 (Table 3). 334 They are described as follows:

$335-\quad$ F1 Carbonate facies with indurated foraminifera-rich carbonate (Table 3, Fig.5). This 336 F1 corresponds to remobilized sediment blocks, which are dated to the OligoceneMiocene period (Tallobre, 2017). This slope instability event has also been described further Northwest by Ingram et al. (2011). sandy fraction (Table 3, Fig.7A-7B-8C). Laminae, sand lenses and bioturbation can be 
observed. Glauconite can (1) infill foraminifer tests whose the moulds can be preserved (Fig.7B, 8C) or (2) form infra-millimetric clasts (Fig.7C-7F). The latter show a high degree of fracturing, irregular shape and they can derive from erosion and transport of slightly lithified glauconitic beds hardground.

F3 Sandy facies. It is characterized by bioturbated foraminifera-rich sand mixed with glauconitic grains (between $0.1 \%$ and $1 \%$ of highly fractured glauconite grains in the sandy fraction, and around $20 \%$ of sand and coarse silt) and joined grains as illustrated on the thin section (Table 3, Fig.7C-8E). Laminae or sand lenses can be found (Fig.7C).

- $\quad$ F4 Foraminifera- and glauconitic-bearing muddy facies with slightly laminated foraminifera rich mud (Table 3), few glauconitic grains (with a proportion lower of $0.1 \%$ ) in the sand fraction (Fig.7D-8D). It can be differentiated from F3 because of the low content of sandy grains and because glauconitic grains are less abundant in the mud and concentrated in bioturbation (Fig. 8A-8B).

- $\quad$ F5 Foraminifera sand composed by foraminiferal sandy facies (20\% of sand and coarse silt) with joined grains and poor in glauconitic grains (Table 3, Fig.7E). The fracturing of grains is moderate to low.

- $\quad$ F6 Foraminifera-bearing muddy facies similar to F5, (rich in foraminifera and rare glauconitic grains). The distinctive difference lies in the proportion of sandy grains (Table 3) that are diluted in the mud and not joined (Fig.7F).

- $\quad$ F7 Muddy facies composed by massive mud (Table 3, Fig.7G) with low foraminifera and rare glauconitic grains.

\section{Comments}

Some of the described facies record contrasted hydrodynamic conditions and may 
- F2 Glauconitic sand and F3 Sandy facies, based on grain size and grain fracturing, associated to degraded organic matter (Tallobre et al., 2016), are characteristic of high winnowing conditions and may correspond to an equivalent of the $\mathrm{C} 3$ contourite sequence.

- F4 Foraminifera- and glauconitic-bearing muddy facies, poorer in sandy grains may relate to the upper part of $\mathrm{C} 2$ with an increasing winnowing effect, whereas the lower part of $\mathrm{C} 4$ should correspond to decreasing winnowing effect.

- F5 Foraminifera sand and F6 Foraminifera-bearing muddy facies, with quite abundant foraminifera tests (the sandy fraction) may correlate to the lower part of $\mathrm{C} 2$ and the upper part of $\mathrm{C} 4$ and a moderate winnowing effect.

- Finally, F7 Muddy facies, the finest in terms of grain size, probably corresponds to an equivalent of units $\mathrm{C} 1$ and $\mathrm{C} 5$. The good organic matter preservation in this facies is consistent with very low winnowing effect (Tallobre et al., 2016).

\section{Glauconite study}

382 Sediments collected in the moat are rich in glaucony (Fig.4-5). On the contrary, sediment 383 from the contouritic drift, as IG-KSF-05 (Fig.3), contain less glauconitic grains and 384 sometimes abundant pyrite can be found (usually anti-correlating the glauconite content).

\section{a. Core IG-KSF-11}

Vertical distribution of glauconitic grains for IG-KSF-11 (Fig.4) has been compared to

$387 \quad \delta^{18} \mathrm{O}$ ratios for correlation with the glacial/interglacial intervals previously defined:

- Between 500-601 cm (chronologically undefined interval), the sediments have a moderate content in glauconitic grains $(0.08 \%$ on average for the bulk sediment), with 
$17 \%$ of yellowish-greenish, $42 \%$ of green and $41 \%$ of dark green grains (with the green shade illustrated in Fig.4);

- Between 400 and $500 \mathrm{~cm}$ (reworked and chronologically undefined interval two high glauconitic grain content peaks stick out (430-440 $\mathrm{cm}$ and $480-490 \mathrm{~cm}): 11 \%$ and 13\% in the bulk sediment and $94 \%$ and $91 \%$ in the sandy fraction (facies F2). The dark green grains represent $95-96 \%$ of glauconitic grains; and 267-371 $\mathrm{cm}$ in MIS 6), the green grain content is moderate (facies F3-F4) to high (facies F2). This is particularly true in the MIS 6 sediments where the green grain content reaches $1.2 \%$ in bulk sediment and $25 \%$ of the sandy fraction. Yellowishgreenish grains are less abundant (up to $15 \%$ in the $267-371 \mathrm{~cm}$ interval), whereas green grains and dark green grains reach high concentrations (50\% and 40\%, respectively). As a general trend, the abundance of glauconitic grains decreases upward from the beginning of the glacial stage (Fig.4).

In core IG-KSF-15 (Fig.5), the interval between 170-470 $\mathrm{cm}$ is composed of an alternation 412 of silty-clay and silty-sandy beds, all rich in glauconitic grains with $47 \%$ of dark green and $41326 \%$ of green grains corresponding to facies F2. The interval corresponding to $120-170 \mathrm{~cm}$ is 414 made of carbonated reworked sediment (facies F1). Although some glauconitic grains are 
415 present between $170-160 \mathrm{~cm}$, the glauconitic concentration remains poor. The top of the core

$416(0-120 \mathrm{~cm})$ is characterized by fine sediments with low content in glauconitic grains (facies

417 F4) and 50\% of yellowish-greenish grains.

\section{SEM observations and microprobe analysis on glauconitic grains}

Under the SEM observation, it has been possible to correlate the increasing colour

darkness to the presence of cracks at the surface of the grain (Fig.9). These cracks become

more abundant and deeper as the grains get darker. Micro-sheets are also observed, more

numerous and more distinct as the green colour becomes darker. They can eventually form a

'rose' structure (Fig.9). These neo-formed sheets gradually fill the intra-grain porosity.

Elementary analyses were performed and compared for the four colour categories of glauconitic grains visually defined. The averages of results for major element compositions are presented in table 4 . The reference mud samples collected correspond to beds with less than $0.1 \%$ of green grains. In the mud, the high value in $\mathrm{Al}_{2} \mathrm{O}_{3}$ suggests the occurrence of kaolinite, but this oxide can also be found too in illite and smectite. The $\mathrm{Mg}$ is generally found in smectite, and to a lesser extent in illite.

On the basis of the obtained results, hereafter the points that can be highlighted:

- Marine mud, on the top of core IG-KSF-11, analysed by X-Ray diffraction, is composed by $25 \%$ of smectite, $35 \%$ of illite and $40 \%$ of kaolinite. The content in $\mathrm{Al}_{2} \mathrm{O}_{3}$ is $18.1 \%, 9 \%$ for $\mathrm{Fe}_{2} \mathrm{O}_{3}$, and $2.5 \%$ for $\mathrm{K}_{2} \mathrm{O}$ (Fig.10).

- In greenish/yellowish grains, the content in $\mathrm{Al}_{2} \mathrm{O}_{3}$ decreases at $8.8 \%$, whereas it increases for $\mathrm{Fe}_{2} \mathrm{O}_{3}$ to $27 \%$ and for $\mathrm{K}_{2} \mathrm{O}$ to $2.9 \%$ (Fig.10). for $\mathrm{Fe}_{2} \mathrm{O}_{3}$ to $30.3 \%$ (and punctually until $33.4 \%$ on Fig.9) and for $\mathrm{K}_{2} \mathrm{O}$ to $3.2 \%$ (Fig.10). 
- The trend continues for dark green grains: decrease for $\mathrm{Al}_{2} \mathrm{O}_{3}$ at 5.6\%, and increase for $\mathrm{Fe}_{2} \mathrm{O}_{3}$ to $34 \%$ and for $\mathrm{K}_{2} \mathrm{O}$ to $4.3 \%$ (Fig.10). only slightly whereas the content in $\mathrm{K}_{2} \mathrm{O}$ continue to progress in average to $5.8 \%$ (Fig 10) and punctually until $6.5 \%$ in $\mathrm{K}_{2} \mathrm{O}$ (Fig.9). potassium also increases, more slowly and keeps up longer than iron.

\section{F. Discussion}

The main weak point in this study is the uncertain chronostratigraphic framework. It has been established by putting together information inferred from different proxy data but it is

449 far from being perfect. Unfortunately, all possible dating methods (applicable to this site) do 450 not allow 1) building a more precise age model; 2) to identify with precision the presence and 451 duration of sediment hiatuses. The uncertainties remain significant, especially before MIS 5. 452 Because of the impossibility of obtaining a better precision, we have limited the 453 chronostratigraphy to the identification of glacial and interglacial stages proposing a 454 correlation with isotope stages, as described in the paragraph 2 , in order to describe the 455 mechanisms at the origin of glauconite formation in the contourite sequences and their 456 possible relation with climate. Despite the significant difficulty to establish a solid 457 chronostratigraphic framework before MIS 5, the studied cores represent quite exceptional 458 sediment archives for correlating the phenomenon of glauconite formation and to establish to 459 what extends this feature can be used as a reliable proxy for paleoceanographic 460 reconstructions. 


\section{Glauconitisation process}

\section{Formation and maturation of green grains}

463

464

465

466

467

During glauconitisation, the enrichment in $\mathrm{K}$ (from $2.9 \%$ to $5.8 \% \mathrm{~K}_{2} \mathrm{O}$, Fig.9-10) and $\mathrm{Fe}$ (from $27 \%$ to $34.2 \% \mathrm{Fe}_{2} \mathrm{O}_{3}$ ) occurs at different rates with glauconite maturation (table 4). The greening of grains expresses enrichment in Fe-smectite and interstratified $\mathrm{Fe}$ smectite/glauconite. The diachronic evolution, between Fe and K, illustrates the fact that iron is incorporated and oxidized rapidly, whereas $\mathrm{K}$ assimilation is a slightly slower process (Fig.10 and table 4). This greening is characterized first, by Fe-smectite neoformation, and then, by neoformation of interlayered minerals. Incorporation of $\mathrm{Mg}, \mathrm{Fe}$ and $\mathrm{K}$ in the mineral structure (Fig.9) is the way to transform smectite into Fe-smectite and then into interstratified $\mathrm{Fe}$-smectite/glauconite. It expresses the chemical evidence of the maturation process of glauconitic grains (Odin, 1988; Giresse and Wiewióra, 2001; Wiewióra et al., 2001; Giresse, 2008; Baldermann et al., 2013; Baldermann et al., 2015; Banerjee et al., 2016).

Greening is controlled by the chemical evolution and oxidation state of Fe. Ferrous Fe is at the origin of the grains green colour and its oxidation in Fe-ferric is responsible for the darkening. The elementary composition is the indicator of mineralogical evolution phases (Fe-smectite, interstratified Fe-smectite/Glauconite, and glauconite). The chemical evolution, and thus the greening, are related to the development of numerous micro-sheets (illustrated on the SEM pictures on the Figure 9) infilling the intra-grain porosity. These characteristics indicate the maturity of glauconitic grains. The multiplication of Fe-smectite and interlayered micro-sheets (see SEM pictures on Fig.9) generates density variations (between original mud and the different mineralogical states (Giresse, 2008)). The greening process is associated with the neoformation of interstratified Fe-smectite/illite by the incorporation of $\mathrm{K}$. The neoformed Fe-smectite, which are hydrated, are less dense. This growing neoformation of hydrated minerals causes the decrease of density and increase of volume. Hence, the 
neoformation generates a pressure inside green grains which induces cracking at the grain

487 surface, well developed and clearly shown on the SEM pictures (Fig.9). These cracks are thus an indicator of the mineralogical maturity of glauconitic grains (Giresse, 2008).

\section{Glauconitisation at the sea/surface interface}

The analyses performed on green grains indicate a geochemical trend and that the greening is accompanied by elementary and mineralogical changes (Fig.9-10).

However, the limiting factor for glauconitisation is the availability of Fe (supplied by the alteration of minerals of continental origin) and $\mathrm{K}$ (directly provided by sea water). In the anoxic mud of deep-sea sediments, iron is mainly present as $\mathrm{Fe}^{2+}$. The rapid oxidation of organic matter causes a redox front between the grain and the surrounding mud, making the micro-environment around the foraminifera more oxidising than the mud matrix (Odin, 1988; Giresse and Wiewióra, 2001; Wiewióra et al., 2001; Giresse, 2008). Thus, $\mathrm{Fe}^{2+}$ migrates rapidly inside foraminifera tests, where it is partly oxidized into $\mathrm{Fe}^{3+}$ and possibly incorporated into octahedral structures; smectites become Fe-smectites (Fig.10.1 and 10.2). This process occurs relatively rapidly at the water/sediment interface. In contrast to $\mathrm{Fe}, \mathrm{K}$ migrates slowly and gradually from seawater into the micro-environment inside buried foraminifera tests below the seafloor to form glauconite assemblages (Fig.10). The interlayer incorporation of $\mathrm{K}$, and consequently glauconitisation, requires a long exposure period at the sea water/sediment interface. If these two conditions are filled, the transformation of detrital clay minerals into Fe-smectite, interlayered Fe-smectite/glauconite and glauconite is possible (Fig.10). The formation of mature glauconitic grains, composed of Fe-smectites and interlayered Fe-smectite/glauconite (with $5 \%$ to $6.5 \% \mathrm{~K}_{2} \mathrm{O}$ in our samples Fig.9), occurs rapidly during the early diagenetic process (about 10 to $100 \mathrm{kyr}$ ). The complete glauconitisation process (with more than $8 \%$ of $\mathrm{K}_{2} \mathrm{O}$ expected (Giresse, 2008)) needs a longer period of time, ranging from 2 to $10 \mathrm{Myr}$ (Odin and Fullagar, 1988; Odin, 1988; Gaudin et al., 
511 2005; Baldermann et al., 2013), and as such often happens during late marine diagenetic

512 processes.

\section{Glauconitisation and winnowing effect}

514 During early diagenesis, glauconitisation occurs at the water/sediment interface with low

515 sedimentation rates to promote the incorporation of Fe and subsequently K (McRae, 1972;

516 Odin, 1988; Giresse and Wiewióra, 2001; Wiewióra et al., 2001; Giresse, 2008). At times,

517 low sedimentation rates can be induced by the winnowing effect linked to bottom current 518 activity (Chafetz and Reid, 2000; Giresse and Wiewióra, 2001; Wiewióra et al., 2001; 519 Giresse, 2008).

In Demerara contouritic sediments, the glauconitic facies (F2) are characterized by high sandy and silt content, high value of $\overline{\mathrm{SS}}$, high fracturing of grains, and an enhanced degradation of organic matter (Tallobre et al., 2016). These elements suggest that the glauconitisation might be related to high winnowing effect. Moreover, the here described glauconitic facies corresponds to sediments collected in the moat (Fig.4-5) stronger bottom water winnowing) whereas this facies is absent in sediments collected in the drift (Fig.3, weaker bottom water winnowing, finer sediments and rare glauconite fracturing features).

As a consequence, we put forward the hypothesis that during the period characterized by the highest current intensity, the winnowing effect inhibits sediment deposition and instead causes erosion at the seafloor and high fracturing of foraminifers' tests. The mud directly in 530 contact with seawater, is more oxidising than in the underlying mud, which can promote the 531 occurrence of a redox front and, likely, glauconitisation (Fig.10).

532 Glauconitisation at the seafloor is concomitant to the formation of indurated beds. 533 Occasionally, during the erosional phases, some coarse clasts can be reworked from the 534 seafloor, deposited and mixed within the glauconitic sandy facies as intraclasts (facies F2, 535 Fig. 8C-8F). 


\section{Glauconite and contourite sequence}

The link between glauconitic grain maturity, winnowing effect and current intensity allows us to propose an alternative 'ideal' contouritic sequence that integrates the glauconite content and its degree of maturity (Fig.11). Thus, units C1 and C5 might correspond to low current velocity muddy facies, with a low glauconitic grain content and maturity (Fig.3 and 4). The $\mathrm{C} 2$ and $\mathrm{C} 4$ mottled muddy facies should record current velocity decrease and subsequent increase, corresponding to negatively and positively graded sediments. Those facies contain abundant glauconitic grains including a mixture of different green grains with dominance of dark green and light green grains. The dark green grain concentration increases with coarsening in $\mathrm{C} 2$, and it decreases in the fining upward of $\mathrm{C} 4$, and inversely for yellowish-greenish grains (Fig.3, 4 and 5). Finally, the C3 sandy facies corresponding to the maximum current velocity is characterized by a high content of dark green grains as illustrated along the cores (Fig.3, 4 and 5). At the maximum of bottom current intensity, during low sedimentation, hardground surfaces might form with possible erosion and formation of glauconitic intraclasts.

\section{Winnowing effect and current velocity Quaternary evolution}

While the evolution of the NADW intensity is still subject to discussion, the results obtained in this study for the Demerara Plateau (IG-KSF-11 and IG-KSF-05) provide further evidence on the factors that may have affected the strength of deep-ocean circulation and its effect on sedimentation in the equatorial western Atlantic. It is necessary to bear in mind that the chronostratigraphic framework obtained on the studied cores is not sufficiently robust for being considered conclusive. However, based on the $\delta^{18} \mathrm{O}$ relative variations and palaeomagnetic records, we propose the distinction between glacial vs interglacial intervals in these cores, in order to discuss the evolution of bottom currents according to climate conditions. 
To resume the features observed in the sediments, the glacial stages are characterised by:

562

563

564

565

566

567

568

569

570

571

572

573

574

575

576

577
- relative high glauconitic grain content;

- $\quad$ high maturity of glauconitic grains;

- $\quad$ sandy facies, rich in sand and coarse silt;

- $\quad$ high degree of fracturing of the shell debris and glauconitic grains;

- largely winnowed organic matter.

Within the intervals corresponding to the full interglacials, it is possible to observe:

- moderate to very low glauconitic content,

- low maturity of glauconitic grains,

- muddy facies, rich in clays and fine silt

- low degree of fracturing of shells,

- better preservation of organic matter.

Taken together, the observed differences between glacial and interglacial sediment characteristics suggest that global climate exerts a strong control on contourite deposition and associated diagenetic processes. Evidence of a high winnowing effect, which coincided with low sedimentation rates caused by a high current velocity, would be consistent with the hypothesis of a vigorous bottom current activity during the glacial periods (Curry and Oppo, 2005; Böhm et al., 2015; Lippold et al., 2016).

Particularly, the degree of glauconite maturity in the cores studied in this work, suggests the presence of an active overturning circulation during the glacial phases in this segment of Atlantic Ocean. Lippold et al. (2016) evidenced the persistence of a vigorous oceanic circulation during the LGM in the relatively shallow (>2000 m depth) Southern Atlantic, but the case of Demerara Plateau is even more peculiar, because of its particular morphology. As stated before, the large indentation is thought to be at the origin of the intensification of the NADW, favouring the formation of contourites (Tallobre et al., 2016). Here, we put forward 
the hypothesis that during glacial stages, the action of overturning circulation could have been amplified by the Demerara Plateau morphology, inducing a strong and prolonged winnowing on sediments as testified by the glauconite neoformation.

\section{G. Conclusion}

This study describes the characteristics of deposits belonging to contourite sequences on the Demerara Plateau, through the detailed analyses of sediment cores retrieved during the IGUANES cruise. A very distinctive sediment feature is the presence of an authigenic mineral, the glauconite, that here is thought to be formed under the effect of bottom water hydrodynamic conditions, since the formation of glaucony might be relatively rapid at the water/sediment interface during the first stage of diagenesis.

In particular, the winnowing effect is very likely at the origin of the formation of 597 glauconite (composed of Fe-smectite and interlayered Fe-smectite/glauconite) that is observed to develop mainly inside foraminifera tests at the sediment-water interface.

The detailed study of glauconite grains allowed to identify the different phases of the 600 glauconitisation process, and characterized by (1) increasing relative abundance of glauconitic grains and (2) increasing degree of mineralogical maturity.

602 The degree of maturity has been defined by (a) grain colour (yellowish green for immature 603 glauconite to dark green for very mature glauconite), (b) the presence of cracks at the grain 604 surface, together with the enrichment in neoformed microstructures and decreasing porosity 605 inside grains and (c) by mineralogical and chemical composition change. The formation of 606 glaucony is relatively rapid at the water/sediment interface during the first stage of diagenesis.

607 Hence, the features of glauconitic grains are here used as an indicator of the winnowing 608 effect. This proxy is thought to have a good potential since it allows a semi-quantitative 
estimation of the current intensity and, combined with other sedimentological and

610 geochemical parameters, could have an interest in studies of contouritic deposits.

611 In this study, the characteristics of glauconitic sediments and their correlation with the 612 major climate shifts, suggest that the NADW flow was strengthened during glacial periods,

613 likely because the local morphology (indentation of the Demarara Plateau) may have 614 generated a strong and prolonged bottom water winnowing.

\section{H. Acknowledgments}

The authors would like to thank the crew of the N/O L'Atalante. We also thank Shell and

617 Ifremer for supporting Cédric Tallobre's PhD Project, Ifremer Brest laboratories for technical 618 support on sediment core handling and analyses (Angélique Roubi, Mikael Rovere, Joël 619 Etoubleau); Bernard Martin at the University of Bordeaux the thin sections; the CEFREM 620 (University of Perpignan), Christophe Menniti, Bruno Charrière, Jennifer Sola, Stéphane 621 Kunesch, Christine Sotin for access to laboratory facilities and assistance. Many thanks to the 622 graduate students who worked on this topic: Camille Ferrer, Lea Bonnin, Simon Faye, 623 Emmanuel Chassagnac. Finally, authors thank reviewers and editors for their contributions to 624 improve this paper.

\section{References}

626 Arz, H.W., Pätzold, J., Wefer, G., 1998. Correlated Millennial-Scale Changes in Surface 627 Hydrography and Terrigenous Sediment Yield Inferred from Last-Glacial Marine Deposits off 628 Northeastern Brazil. Quaternary Research 50, 157-166.

629 Arz, H.W., Pätzold, J., Wefer, G., 1999. Climatic changes during the last deglaciation 630 recorded in sediment cores from the northeastern Brazilian Continental Margin. Geo-Marine 631 Letters 19, 209-218.

632 Bahk, J.J., Chough, S.K., Jeong, K.S., Han, S.J., 2001. Sedimentary records of 633 paleoenvironmental changes during the last deglaciation in the Ulleung Interplain Gap, East 634 Sea (Sea of Japan). Global and Planetary Change 28, 241-253.

635 Bahk, J.J., Lee, S.H., Yoo, H.S., Back, G.G., Chough, S.K., 2005. Late Quaternary 636 sedimentary processes and variations in bottom-current activity in the Ulleung Interplain Gap, 637 East Sea (Korea). Marine Geology 217, 119-142. 
Baldermann, A., Deditius, A.P., Dietzel, M., Fichtner, V., Fischer, C., Hippler, D., Leis, A., Baldermann, C., Mavromatis, V., Stickler, C.P., Strauss, H., 2015. The role of bacterial sulfate reduction during dolomite precipitation: Implications from Upper Jurassic platform carbonates. Chemical Geology 412, 1-14.

642 Baldermann, A., Warr, L.N., Grathoff, G.H., Dietzel, M., 2013. The rate and mechanism of deep-sea glauconite formation at the ivory coast-ghana marginal ridge. Clays and Clay Minerals 61, 258-276.

Banerjee, S., Bansal, U., Vilas Thorat, A., 2016. A review on palaeogeographic implications and temporal variation in glaucony composition. Journal of Palaeogeography 5, 43-71. Barbetti, M., Taborin, Y., Schmider, B., Flude, K., 1980. Archaeomagnetic results from late Pleistocene hearths at Etiolles and Marsangy, France. Archaeometry 22, 25-46.

Bleil, U., Von Dobeneck, T., 1999. Geomagnetic events and relative paleointensity recordsClues to high-resolution paleomagnetic chronostratigraphies of Late Quaternary marine sediments?, Use of proxies in paleoceanography. Springer, pp. 635-654.

660 Curry, W.B., Oppo, D.W., 2005. Glacial water mass geometry and the distribution of $\delta 13 \mathrm{C}$ of $\Sigma \mathrm{CO} 2$ in the western Atlantic Ocean. Paleoceanography 20.

Böhm, E., Lippold, J., Gutjahr, M., Frank, M., Blaser, P., Antz, B., Fohlmeister, J., Frank, N., Andersen, M., Deininger, M., 2015. Strong and deep Atlantic meridional overturning circulation during the last glacial cycle. Nature 517, 73-76.

Bonhommet, N., Babkine, J., 1967. Sur la presence d'aimantations inversees dans la Chaine des Puys. Comptes rendus hebdomadaires des seances de 1 academie des sciences serie b 264, 92-94.

664 Faugères, J.-C., Zaragosi, S., Mézerais, M., Massé, L., 2002. The Vema contourite fan in the 665 South Brazilian basin. Geological Society, London, Memoirs 22, 209-222.

666 Faugères, J.C., Mulder, T., 2011. Contour Currents and Contourite Drifts. in: Heiko Hüneke 667 and Thierry Mulder, Deep sea sediments, elseiver publications, developments in sedimentology 63, 149-205. Gaudin, A., Buatier, M., Beaufort, D., Petit, S., Grauby, O., Decarreau, A., 2005.
Characterization and origin of Fe3+-montmorillonite in deep-water calcareous sediments (Pacific Ocean, Costa Rica margin). Clays and Clay Minerals 53, 452-465.

Gaullier, V., Loncke, L., Droz, L., Basile, C., Maillard, A., Patriat, M., Roest, W.R., Loubrieu, B., Folens, L., Carol, F., 2010. Slope instability on the French Guiana transform margin from swath-bathymetry and $3.5 \mathrm{kHz}$ echograms, Submarine Mass Movements and Their Consequences. Springer, pp. 569-579.

Gibbard, P., Cohen, K.M., 2008. Global chronostratigraphical correlation table for the last 2.7 million years. Episodes 31, 243-247.

Giresse, P., 2008. Chapter 12 Some Aspects of Diagenesis in Contourites, In: Rebesco, M., Camerlenghi, A. (Eds.), Developments in Sedimentology. Elsevier, pp. 203-221.

Giresse, P., Wiewióra, A., 2001. Stratigraphic condensed deposition and diagenetic evolution of green clay minerals in deep water sediments on the Ivory Coast-Ghana Ridge. Marine Geology 179, 51-70.

Gonthier, E., Faugères, J.C., Stow, D.A.V., 1984. Contourite facies of the Faro drift. Geological society of London, special publication 15, 275-292. 
Guillou, H., Singer, B.S., Laj, C., Kissel, C., Scaillet, S., Jicha, B.R., 2004. On the age of the Laschamp geomagnetic excursion. Earth and Planetary Science Letters 227, 331-343.

Heezen, B.C., 1959. Dynamic Processes of Abyssal Sedimentation: Erosion, Transportation, and Redeposition on the Deep-sea floor. Geophysical Journal International 2, 142-163.

Heezen, B.C., Hollister, C., 1964. Deep-sea current evidence from abyssal sediments. Marine Geology 1, 141-174.

Heezen, B.C., Johnson, G.L., 1963. A moated knoll in the Canary Passage. Dent. Hydrograph. Z. 16, 269-272.

Hernández-Molina, F.J., Paterlini, M., Violante, R., Marshall, P., de Isasi, M., Somoza, L., Rebesco, M., 2009. Contourite depositional system on the Argentine Slope: An exceptional record of the influence of Antarctic water masses. Geology 37, 507-510.

Hurley, P., Rand, J., Pinson, W., Fairbairn, H., de Almeida, F., Melcher, G., Cordani, U., Kawashita, K., Vandoros, P., 1967. Test of Continental Drift by Comparison of Radiometric Ages A pre-drift reconstruction shows matching geologic age provinces in West Africa and Northern Brazil. Science 157, 495-500.

Ingram, W.C., 2006. Anatomy of Oligocene-Miocene debris flow and slumps form Demerara Rise: implications for margin destruction American Association of Petroleum Geologists 2006 annual Convention, Houston.

Ingram, W.C., Mosher, D.C., Wise, S.W.J., 2011. Biostratigraphy of an upper Miocene mass transport deposit on Demerara Rise, northern South American margin, In: Shipp, C., Weimer, P., Posamentier, H. (Eds.), Mass-transport Deposits in Deepwater Settings. SEPM Special Publication 96, pp. 457-498.

Kageyama, M., Merkel, U., Otto-Bliesner, B., Prange, M., Abe-Ouchi, A., Lohmann, G., Ohgaito, R., Roche, D., Singarayer, J., Swingedouw, D., 2013. Climatic impacts of fresh water hosing under Last Glacial Maximum conditions: a multi-model study. Climate of the Past 9, 935-953.

Lee, S.H., Bahk, J.J., Chough, S.K., Back, G.G., Yoo, H.S., 2004. Late Quaternary sedimentation in the Ulleung Interplain Gap, East Sea (Korea). Marine Geology 206, 225248.

Lippold, J., Gutjahr, M., Blaser, P., Christner, E., de Carvalho Ferreira, M.L., Mulitza, S., Christl, M., Wombacher, F., Böhm, E., Antz, B., 2016. Deep water provenance and dynamics of the (de) glacial Atlantic meridional overturning circulation. Earth and Planetary Science Letters 445, 68-78.

Lisiecki, L.E., Raymo, M.E., 2005. A Pliocene-Pleistocene stack of 57 globally distributed benthic $\delta 180$ records. Paleoceanography 20.

Lisiecki, L.E., Raymo, M.E., 2009. Diachronous benthic $\delta 180$ responses during late Pleistocene terminations. Paleoceanography.

Loncke, L., Droz, L., Gaullier, V., Basile, C., Patriat, M., Roest, W., 2009. Slope instabilities from echo-character mapping along the French Guiana transform margin and Demerara abyssal plain. Marine and Petroleum Geology 26, 711-723.

Loncke, L., Maillard, A., Basile, C., Roest, W.R., Bayon, G., Gaullier, V., Pattier, F., Mercier de Lépinay, M., Grall, C., Droz, L., Marsset, T., Giresse, P., Caprais, J.C., Cathalot, C., Graindorge, D., Heuret, A., Lebrun, J.F., Bermell, S., Marcaillou, B., Sotin, C., Hebert, B., Patriat, M., Bassetti, M.A., Tallobre, C., Buscail, R., Durrieu de Madron, X., Bourrin, F., 2016. Structure of the Demerara passive-transform margin and associated sedimentary processes. Initial results from the IGUANES cruise. Geological Society, London, Special Publications 431. 
Lopes, R.P., Kinoshita, A., Baffa, O., Figueiredo, A.M.G., Dillenburg, S.R., Schultz, C.L., Pereira, J.C., 2014. ESR dating of Pleistocene mammals and marine shells from the coastal plain of Rio Grande do Sul state, southern Brazil. Quaternary International 352, 124-134. López-Otálvaro, G.-E., Flores, J., Sierro, F., Cacho, I., Grimalt, J.-O., Michel, E., Cortijo, E., Labeyrie, L., 2009. Late Pleistocene palaeoproductivity patterns during the last climatic cycle in the Guyana Basin as revealed by calcareous nannoplankton. EEarth 4, 1-13.

Lund, S.P., Schwartz, M., Keigwin, L., Redefinition of the Blake Event.

Maley, J., Livingstone, D.A., Giresse, P., Thouveny, N., Brenac, P., Kelts, K., Kling, G., Stager, C., Haag, M., Fournier, M., Bandet, Y., Williamson, D., Zogning, A., 1990. Lithostratigraphy, volcanism, paleomagnetism and palynology of Quaternary lacustrine deposits from Barombi Mbo (West Cameroon): Preliminary results. Journal of Volcanology and Geothermal Research 42, 319-335.

McCave, I., Manighetti, B., Robinson, S., 1995. Sortable silt and fine sediment size/composition slicing: parameters for palaeocurrent speed and palaeoceanography. Paleoceanography 10, 593-610.

McCave, I.N., Hall, I.R., 2006. Size sorting in marine muds: Processes, pitfalls, and prospects for paleoflow-speed proxies. Geochemistry, Geophysics, Geosystems 7, 1-37.

749 McRae, S.G., 1972. Glauconite. Earth-Science Reviews 8, 397-440.

750

751

752

753

754

755

756

757

758

759

760

761

762

763

764

765

766

767

768

769

770

771

772

773

774

775

776

777

778

Menviel, L., Timmermann, A., Friedrich, T., England, M., 2014. Hindcasting the continuum of Dansgaard-Oeschger variability: mechanisms, patterns and timing. Climate of the Past 10, 63-77.

Mercier de Lépinay, M., Loncke, L., Basile, C., Roest, W., Patriat, M., Maillard, A., De Clarens, P., 2016. Transform continental margins - Part 2: A worldwide inventory. Tectonophysics.

Mörner, N.-A., 1977. The Gothenburg Magnetic Excursion. Quaternary Research 7, 413-427.

Mörner, N.-A., 1986. Geomagnetic excursions in late Brunhes time, European long-core data. Physics of the Earth and Planetary Interiors 44, 47-52.

Mosblech, N.A., Bush, M.B., Gosling, W.D., Hodell, D., Thomas, L., van Calsteren, P., Correa-Metrio, A., Valencia, B.G., Curtis, J., van Woesik, R., 2012. North Atlantic forcing of Amazonian precipitation during the last ice age. Nature Geoscience 5, 817-820.

Müller-Karger, F., McClain, C., Fisher, T., Esaias, W., Varela, R., 1989. Pigment distribution in the Caribbean Sea: Observations from space. Progress in Oceanography 23, 23-64.

Nace, T.E., Baker, P.A., Dwyer, G.S., Silva, C.G., Rigsby, C.A., Burns, S.J., Giosan, L., OttoBliesner, B., Liu, Z., Zhu, J., 2014. The role of North Brazil Current transport in the paleoclimate of the Brazilian Nordeste margin and paleoceanography of the western tropical Atlantic during the late Quaternary. Palaeogeography, Palaeoclimatology, Palaeoecology 415, $3-13$.

Odin, G., Fullagar, P., 1988. Chapter C4 geological significance of the glaucony facies. Developments in sedimentology 45, 295-332.

Odin, G.S., 1988. Green Marine Clays. Elsevier.

Pattier, F., Loncke, L., Gaullier, V., Basile, C., Maillard, A., Imbert, P., Roest, W.R., Vendeville, B.C., Patriat, M., Loubrieu, B., 2013. Mass-transport deposits and fluid venting in a transform margin setting, the eastern Demerara Plateau (French Guiana). Marine and Petroleum Geology 46, 287-303.

Pattier, F., Loncke, L., Imbert, P., Gaullier, V., Basile, C., Maillard, A., Roest, W.R., Patriat, M., Vendeville, B.C., 2015. Origin of an enigmatic regional Mio-Pliocene unconformity on the Demerara plateau. Marine Geology 365, 21-35. 
Plenier, G., Valet, J.-P., Guérin, G., Lefèvre, J.-C., LeGoff, M., Carter-Stiglitz, B., 2007. Origin and age of the directions recorded during the Laschamp event in the Chaîne des Puys (France). Earth and Planetary Science Letters 259, 414-431.

782

783

784

785

786

787

788

789

790

791

792

793

794

795

796

797

798

799

800

801

802

803

804

805

806

807

808

809

810

811

812

813

814

815

816

817

818

819

820

821

822

823

824

Rama-Corredor, O., Martrat, B., Grimalt, J.O., López-Otalvaro, G.E., Flores, J.A., Sierro, F., 2015. Parallelisms between sea surface temperature changes in the western tropical Atlantic (Guiana Basin) and high latitude climate signals over the last 140000 years. Climate of the Past 11, 1297-1311.

Rebesco, M., Camerlenghi, A., 2008. Contourites. Elseiver.

Rebesco, M., Hernández-Molina, F.J., Van Rooij, D., Wåhlin, A., 2014. Contourites and associated sediments controlled by deep-water circulation processes: State-of-the-art and future considerations. Marine Geology 352, 111-154.

Reimer, P., Bard, E., Bayliss, A., Beck, J., Blackwell, P., Bronk Ramsey, C., Buck, C., Cheng, H., Edwards, R., Friedrich, M., Grootes, P., Guilderson, T., Haflidason, H., Hajdas, I., Hatté, C., Heaton, T., Hogg, A., Hughen, K., Kaiser, K., Kromer, B., Manning, S., Niu, M., Reimer, R., Richards, D., Scott, E., Southon, J., Turney, C., van der Plicht, J., 2013. IntCal13 and MARINE13 radiocarbon age calibration curves 0-50000 years calBP Radiocarbon 55(4).

Shackleton, N.J., Sánchez-Goñi, M.F., Pailler, D., Lancelot, Y., 2003. Marine Isotope Substage 5e and the Eemian Interglacial. Global and Planetary Change 36, 151-155.

Shanmugam, G., 2016. The contourite problem. Sediment Provenance.

Smith, G., Creer, K.M., 1986. Analysis of geomagnetic secular variations 10000 to 30000 years bp, Lac du Bouchet, France. Physics of the Earth and Planetary Interiors 44, 1-14.

Smith, J.D., Foster, J.H., 1969. Geomagnetic reversal in Brunhes normal polarity epoch. Science 163, 565-567.

Stow, D., Faugères, J.-C., 2008a. Contourite facies and the facies model. Developments in Sedimentology 60, 223-256.

Stow, D.A.V., Faugères, J.-C., Howe, J.A., Pudsey, C.J., Viana, A.R., 2002. Bottom currents, contourites and deep-sea sediment drifts: current state-of-the-art. Bottom currents, contourites and deep-sea sediment drifts: current state-of-the-art. In: Stow, D.A.V., Pudsey, C.J., Howe, J.A., Faugères, J.-C., Viana, A.R. (Eds.), Deep-Water Contourite Systems: Modern Drifts and Ancient Series, Seismic and Sedimentary Characteristics: Geological Society London Memoir 22, 137-154.

Stow, D.A.V., Faugères, J.C., 2008b. Chapter 13 Contourite Facies and the Facies Model, In: Rebesco, M., Camerlenghi, A. (Eds.), Developments in Sedimentology. Elsevier, pp. 223-256.

Tallobre, C., 2017. Mise en évidence d'un système de dépôt contouritique et des processus sédimentaires associés sur le plateau de Demerara (marge guyanaise), Cefrem. Université de Perpignan via Domitia, Perpignan.

Tallobre, C., Loncke, L., Bassetti, M.-A., Giresse, P., Bayon, G., Buscail, R., de Madron, X.D., Bourrin, F., Vanhaesebroucke, M., Sotin, C., 2016. Description of a contourite depositional system on the Demerara Plateau: Results from geophysical data and sediment cores. Marine Geology 378, 56-73.

Thouveny, N., Williamson, D., 1988. Palaeomagnetic study of the Holocene and Upper Pleistocene sediments from Lake Barombi Mbo, Cameroun: first results. Physics of the Earth and Planetary Interiors 52, 193-206.

Tudryn, A., Tucholka, P., Gibert, E., Gasse, F., Wei, K., 2010. A late Pleistocene and Holocene mineral magnetic record from sediments of Lake Aibi, Dzungarian Basin, NW China. Journal of Paleolimnology 44, 109-121. 
825 van der Hammen, T., Absy, M.L., 1994. Pollen and ClimateAmazonia during the last glacial. 826 Palaeogeography, Palaeoclimatology, Palaeoecology 109, 247-261.

827 Viana, A.R., Faugeres, J.C., Kowsmann, R.O., Lima, J.A.M., Caddah, L.F.G., Rizzo, J.G., 828 1998. Hydrology, morphology and sedimentology of the Campos continental margin, offshore 829 Brazil. Sedimentary Geology 115, 133-157.

830 Wiewióra, A., Giresse, P., Petit, S., Wilamowski, A., 2001. A deep-water glauconitization 831 process on the Ivory Coast-Ghana marginal ridge (ODP site 959): determination of Fe3+-rich 832 montmorillonite in green grains. Clays and Clay Minerals 49, 540-558.

833 Zaragosi, S., Bourillet, J.-F., Eynaud, F., Toucanne, S., Denhard, B., Van Toer, A., Lanfumey, 834 V., 2006. The impact of the last European deglaciation on the deep-sea turbidite systems of 835 the Celtic-Armorican margin (Bay of Biscay). Geo-Marine Letters 26, 317-329. 
837 Table 1: Radiocarbon dates for well-preserved Globigerinoides sp. fractions from samples

838 collected from core IG-KSF-11. The calibrated ages were calculated using Calib 7.0.4 with

839 the Marine 09 calibration curve (Reimer et al., 2013).

840 Table 2: Tie points identified in the IG-KSF-05 and IG-KSF-11 core based on correlation

841 with reference oxygen isotope curves (Martinson et al., 1987; Walker et al., 2009)

842 Table 3: Sedimentary facies table based on the description of core, microscopic observation

843 (sand fraction and thin section).

844 Table 4: Average chemical composition measured by microprobe coupled to the SEM on mud 845 and on green grains coming from the core IG-KSF-11 at different depth on the core $(0 \mathrm{~cm}, 60$ $846 \mathrm{~cm}, 70 \mathrm{~cm}, 90 \mathrm{~cm}, 300 \mathrm{~cm}, 420 \mathrm{~cm}, 442 \mathrm{~cm}, 460 \mathrm{~cm}, 590 \mathrm{~cm})$. For each grain, 2 measures

847 was performed, results the average is established in function of the grain colour (yellowish848 green, green, and dark green, the last one being sub-divided into dark and very dark green).

849 Figure 1: General map and location of the study area with position of North Atlantic Deep 850 water (NADW) and Antarctic Bottom Water (AABW).

851 Figure 2: Bathymetric map with the position of cores analysed in this paper. The core IG852 KSF-05 was collected inside the drift of the Demerara Contourite Depositional System (CDS) 853 whereas the core IG-KSF-11 and IG-KSF-15 were collected inside the moat of this CDS.

854 Figure 3: Sedimentary log of core IG-KSF-05, collected in the sedimentary drift, presenting 855 the identified sedimentary facies (more details about facies in table 3), the planktic 856 (Globigerina ruber) and benthic (Uvigerina mediterranea) oxygen isotope records, the 857 palaeomagnetism record (NRM, inclination and declination), glauconitic grain concentration 858 on bulk sediment (total green grains with the green curve) and Ca XRF record.

859 Figure 4: Sedimentary log of core IG-KSF-11, collected in the contouritic moat, illustrating 860 the identified sedimentary facies (more details about facies in table 3), planktic (Globigerina 
ruber) and benthic (Uvigerina mediterranea) oxygen isotope record, the palaeomagnetism record (NRM, inclination and declination), glauconitic grain quantification on bulk sediment (total green grains with the green curve, and the bars represent the relative content in function of the greening (yellowish, green and dark green grains), the sortable silt on the freecarbonated record and Ca XRF record.

Figure 5: Sedimentary log of core IG-KSF-15, collected in the moat, with glauconitic grain quantitative estimation on bulk sediment (total green grains with the green curve) and $\mathrm{Ca}$ XRF record.

869 Figure 6: Reference isotopic curves of Guyana (López-Otálvaro et al., 2009), a global curve 870 for the Atlantic domain (Lisiecki and Raymo, 2005; Lisiecki and Raymo, 2009; Lopes et al., 871 2014), North Brazil (Arz et al., 1998), and IGUANES data for cores IG-KSF-05 and IG-KSF87211.

873 Figure 7: Thin section photos illustrating the different micro-facies F2 to F7 (see table 3).

874 Figure 8: Thin section $\mathrm{s}$ of some sediment facies. (F: foraminifera, G.If: glauconitic infilling, 875 Gic: glauconitic intraclast, GM: glauconitic mould, Qz: quartz)

876 Figure 9: Illustration of the degree of glauconitic maturity. The different degrees of maturity 877 are illustrated by the colour of grains, the structure at the grain surface with MEB picture, the 878 micro-structure with MEB picture, and the elementary composition measured by microprobe 879 which is one-time the on the single related grain.

880 Figure 10: Schematic evolution of glauconitic grains from pristine marine mud to dark green 881 grains with the mean elementary composition measured by microprobe and established for 882 each class colour with the two values on each grain.

883 Figure 11: Schema of the ideal contouritic sequence (modified from (Stow and Faugères 884 (2008a)) and according to the glauconitisation processes. The concentration and the 885 mineralogic maturity of the green grains increase with the winnowing intensity. 
ACCEPTED MANUSCRIPT

\begin{tabular}{|c|c|c|c|c|c|c|}
\hline \multirow[t]{2}{*}{$\begin{array}{l}\text { Depth core } \\
(\mathrm{cm})\end{array}$} & \multirow[t]{2}{*}{ Core } & \multirow[t]{2}{*}{$\overline{\text { Material }}$} & \multirow[t]{2}{*}{$\begin{array}{l}\text { Age }{ }^{14} \mathrm{C} \\
(\mathrm{yr} B \mathrm{P})\end{array}$} & \multicolumn{3}{|c|}{$\begin{array}{c}1 \text { sigma calibrated age } \\
\text { (yr cal. BP) }\end{array}$} \\
\hline & & & & $\min$ & $\max$ & average \\
\hline 0 & IG-KSF-11 & Globigerinoides sp. & $13930 \pm 80 \mathrm{BP}$ & 14201 & 14466 & 14334 \\
\hline 60 & IG-KSF-11 & Globigerinoides sp. & $\begin{array}{c}34400 \pm 600 \\
\text { BP }\end{array}$ & 35630 & 37248 & 36439 \\
\hline 130 & IG-KSF-11 & Globigerinoides sp. & $\begin{array}{c}37100 \pm 800 \\
B P\end{array}$ & 38560 & 39974 & 39267 \\
\hline 130 & IG-KSF-11 & Globigerinoides sp. & $\begin{array}{c}50000 \pm 4000 \\
B P\end{array}$ & & 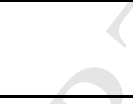 & \\
\hline 313 & IG-KSF-11 & Globigerinoides sp. & $\begin{array}{c}42700 \pm 1500 \\
B P\end{array}$ & 42287 & 45138 & 43713 \\
\hline 452 & IG-KSF-11 & Globigerinoides sp. & $\begin{array}{c}48000 \pm 3000 \\
B P\end{array}$ & - & - & - \\
\hline 530 & IG-KSF-11 & Globigerinoides sp. & $\begin{array}{c}49000 \pm 4000 \\
B P\end{array}$ & - & - & - \\
\hline 530 & IG-KSF-11 & Mud organic matter & $\begin{array}{c}26170 \pm 450 \\
B P \\
\end{array}$ & 27519 & 28574 & 28047 \\
\hline 582 & IG-KSF-11 & Globigerinoides sp. & $\begin{array}{c}39700 \pm 1100 \\
B P\end{array}$ & 40675 & 42385 & 41530 \\
\hline 600 & IG-KSF-11 & Globigerinoides sp. & $\begin{array}{c}35300 \pm 700 \\
B P\end{array}$ & 36716 & 38227 & 37472 \\
\hline 600 & IG-KSF-11 & Globigerinoides sp. & $\begin{array}{c}28400 \pm 200 \\
B P\end{array}$ & 29479 & 30059 & 29769 \\
\hline 0 & IG-KSF-05 & Globigerinoides sp. & $5640 \pm 40 \mathrm{BP}$ & 4027 & 4158 & 4093 \\
\hline 290 & IG-KSF-05 & Globigerinoides $s p$. & $\begin{array}{c}17460 \pm 100 \\
B P \\
\end{array}$ & 18485 & 18763 & 18624 \\
\hline 50 & IG-KSF-05 & Globigerinoides sp. & $\begin{array}{c}34400 \pm 600 \\
\text { BP }\end{array}$ & 34991 & 36551 & 35771 \\
\hline 169 & IG-KSF-05 & Globigerinoides sp. & $\begin{array}{c}37910 \pm 870 \\
B P\end{array}$ & 39262 & 40584 & 39923 \\
\hline 250 & IG-KSF-05 & Globigerinoides sp. & $\begin{array}{c}30600 \pm 400 \\
B P \\
\end{array}$ & 31965 & 32617 & 32291 \\
\hline 250 & IG-KSF-05 & Mud organic matter & $\begin{array}{c}24370 \pm 230 \\
B P \\
\end{array}$ & 26154 & 26661 & 26408 \\
\hline 340 & IG-KSF-05 & Globigerinoides sp. & $\begin{array}{c}44000 \pm 3000 \\
B P\end{array}$ & 42912 & 47381 & 45147 \\
\hline 490 & IG-KSF-05 & Globigerinoides $s p$. & $\begin{array}{c}41000 \pm 2000 \\
B P\end{array}$ & 41339 & 43001 & 42170 \\
\hline 657 & IG-KSF-05 & Globigerinoides sp. & $>43000 \mathrm{BP}$ & - & - & - \\
\hline
\end{tabular}

table 1: Radiocarbon dates for well-preserved Globigerinoides sp. fractions from samples collected from core IG-KSF-11. The calibrated ages were calculated using Calib 7.0.4 with the Marine 09 calibration curve (Reimer et al., 2013) 
IG-KSF-05

\begin{tabular}{|c|c|c|c|}
\hline Intervals & $\begin{array}{c}\text { Duration } \\
(\mathrm{kyr})\end{array}$ & stade & source \\
\hline $0-18$ & $0-11.7$ & MIS 1 & \multirow{2}{*}{ Martinson } \\
et al., 1987; \\
Walter et \\
al., 2009
\end{tabular}

IG-KSF-11

\begin{tabular}{|c|c|c|c|}
\hline Intervals & $\begin{array}{l}\text { Duration } \\
\text { (kyr) }\end{array}$ & stade & source \\
\hline $0-10$ & $0-11.7$ & MIS 1 & \multirow{8}{*}{$\begin{array}{c}\text { Martinson } \\
\text { et al., 1987; } \\
\text { Walter et } \\
\text { al., } 2009\end{array}$} \\
\hline $10-43$ & 11.7-24.1 & MIS 2 & \\
\hline $43-80$ & 24.1-58.9 & MIS 3 & \\
\hline $80-150$ & 58.9-74 & MIS 4 & \\
\hline $150-267$ & $74-130$ & MIS 5 & \\
\hline $267-371$ & 130-189.6 & MIS 6 & \\
\hline $\begin{array}{c}371-422 \\
?\end{array}$ & 189.6-244 & MIS 7 & \\
\hline$?$ & $244-291$ & MIS 8 & \\
\hline
\end{tabular}

Table 2 : Tie points identified in the IG-KSF-05 and IG-KSF-11 core based on correlation with reference oxygen isotope curves (Martinson et al., 1987; Walker et al., 2009) 


\begin{tabular}{|c|c|c|c|c|c|c|}
\hline & Characterisitc & Components & Glaucony maturity & $\begin{array}{l}\text { Fracturation of } \\
\text { components }\end{array}$ & Structure & $\begin{array}{l}\text { Environment } \\
\text { interpretation }\end{array}$ \\
\hline $\begin{array}{l}\text { F1 - Carbonate } \\
\text { facies }\end{array}$ & $\begin{array}{l}\text { Rich in carbonate, indurated } \\
\text { mass, low hydratation of } \\
\text { sediments }\end{array}$ & $\begin{array}{l}\text { - Rare glaucony } \\
\text {-Some iron oxyde } \\
\text { - Foramnifera rich }\end{array}$ & & Low to medium & Absence & $\begin{array}{l}\text { Mass Transoprt } \\
\text { Deposit }\end{array}$ \\
\hline \multirow{2}{*}{$\begin{array}{l}\text { F2 - Glauconitic } \\
\text { facies }\end{array}$} & Glaucony rich & $\begin{array}{l}\text { - Glaucony rich } \\
\text { - Foramnifera rich }\end{array}$ & $\begin{array}{l}\text { - Dark green } \\
\text { - Clasts }\end{array}$ & $\begin{array}{l}\text { Medium to } \\
\text { high }\end{array}$ & $\begin{array}{l}\text { - Bioturbation rich } \\
\text { - Sandy foraminifera } \\
\text { laminae }\end{array}$ & Contourites \\
\hline & Glaucony rich & $\begin{array}{l}\text { - Glaucony rich } \\
\text { - Foramnifera rich }\end{array}$ & $\begin{array}{c}\text { - Dark green } \\
\text { - Inside foramnifera or with } \\
\text { foraminifera shape }\end{array}$ & $\begin{array}{l}\text { Medium to } \\
\text { high }\end{array}$ & $\begin{array}{l}\text { - Bioturbation rich } \\
\text { - Sandy foraminifera } \\
\text { laminae }\end{array}$ & Contourites \\
\hline F3 - Sandy facies & $\begin{array}{l}\text { Foraminifera rich, glauony in } \\
\text { foraminifera }\end{array}$ & $\begin{array}{c}\text { - Glaucony rich } \\
\text { - Foramnifera rich } \\
\text { - Quartz in biotrubation }\end{array}$ & $\begin{array}{l}\text { - Light to dark green } \\
\text { - Inside foramnifera or with } \\
\text { foraminifera shape }\end{array}$ & $\begin{array}{l}\text { Medium to } \\
\text { high }\end{array}$ & $\begin{array}{l}\text { - Bioturbation rich } \\
\text { - Sandy foraminifera } \\
\text { laminae }\end{array}$ & Contourites \\
\hline $\begin{array}{l}\text { F4 - Foraminifera- } \\
\text { and glauconitic- } \\
\text { bearing Muddy } \\
\text { facies }\end{array}$ & $\begin{array}{c}\text { Glaucony and foraminifera } \\
\text { rich }\end{array}$ & $\begin{array}{c}\text { - Some glaucony } \\
\text { - Foramnifera rich } \\
\text {-Some iron oxyde } \\
\text { - Quartz in biotrubation }\end{array}$ & $\begin{array}{l}\text { - Glaucony in foraminifera } \\
\text { test or with foraminifera } \\
\text { shape } \\
\text { - Light to medium green }\end{array}$ & Low to medium & Bioturbation rich & Contourites \\
\hline $\begin{array}{l}\text { F5 - Foraminifera } \\
\text { sand }\end{array}$ & $\begin{array}{l}\text { Foraminifera rich without } \\
\text { glaucony }\end{array}$ & - Rare foramnifera & $\begin{array}{l}\text { - Low glaucony and } \\
\text { sometimes none glaucony }\end{array}$ & Low & Bioturbation rich & Hemipelagite \\
\hline $\begin{array}{l}\text { F6 - Foraminifera } \\
\text { bearing Muddy } \\
\text { facies }\end{array}$ & $\begin{array}{l}\text { Foraminifera rich with little } \\
\text { glaucony }\end{array}$ & $\begin{array}{l}\text { - Rare glaucony } \\
\text { - Foramnifera rare } \\
\text {-Some iron oxyde }\end{array}$ & $\begin{array}{l}\text { - Low glaucony and } \\
\text { sometimes none glaucony }\end{array}$ & Low & $\begin{array}{l}\text { - Bioturbation rich } \\
\text { - Sandy foraminifera } \\
\text { lenses }\end{array}$ & Hemipelagite \\
\hline F7 - Muddy facies & $\begin{array}{l}\text { Very fine matrix and grains } \\
\text { poor }\end{array}$ & $\begin{array}{l}\text { - Rare glaucony } \\
\text { - Foramnifera rare } \\
\text {-Some iron oxyde }\end{array}$ & $\begin{array}{l}\text { - Low glaucony and } \\
\text { sometimes none glaucony }\end{array}$ & Low & $\begin{array}{l}\text { Low to high } \\
\text { Bioturbation }\end{array}$ & Hemipelagite \\
\hline
\end{tabular}




\begin{tabular}{|c|c|c|c|c|c|}
\cline { 2 - 6 } \multicolumn{1}{c|}{} & $\mathrm{Al}_{2} \mathrm{O}_{3}$ & $\mathrm{MgO}$ & $\mathrm{Fe}_{2} \mathrm{O}_{3}$ & $\mathrm{~K}_{2} \mathrm{O}$ & $\mathrm{SiO}_{2}$ \\
\hline Mud & $18.1 \%$ & $1.6 \%$ & $9.0 \%$ & $2.5 \%$ & $46.8 \%$ \\
\hline $\begin{array}{c}\text { Greenish/ } \\
\text { yellowish grain }\end{array}$ & $8.8 \%$ & $2.9 \%$ & $27.0 \%$ & $2.9 \%$ & $47.1 \%$ \\
\hline Green grain & $7.4 \%$ & $3.6 \%$ & $30.3 \%$ & $3.2 \%$ & $51.2 \%$ \\
\hline Dark green grain & $5.6 \%$ & $3.3 \%$ & $34.0 \%$ & $4.3 \%$ & $49.1 \%$ \\
\hline $\begin{array}{c}\text { Very dark green } \\
\text { grain }\end{array}$ & $5.8 \%$ & $3.1 \%$ & $34.2 \%$ & $5.4 \%$ & $48.6 \%$ \\
\hline
\end{tabular}

Table 4 : Average chemical composition measured by microprobe coupled to the SEM on mud and on green grains coming from the core IG-KSF-11 at different depth on the core $(0 \mathrm{~cm}, 60 \mathrm{~cm}, 70 \mathrm{~cm}, 90 \mathrm{~cm}, 300 \mathrm{~cm}, 420 \mathrm{~cm}, 442 \mathrm{~cm}, 460 \mathrm{~cm}, 590 \mathrm{~cm})$. 


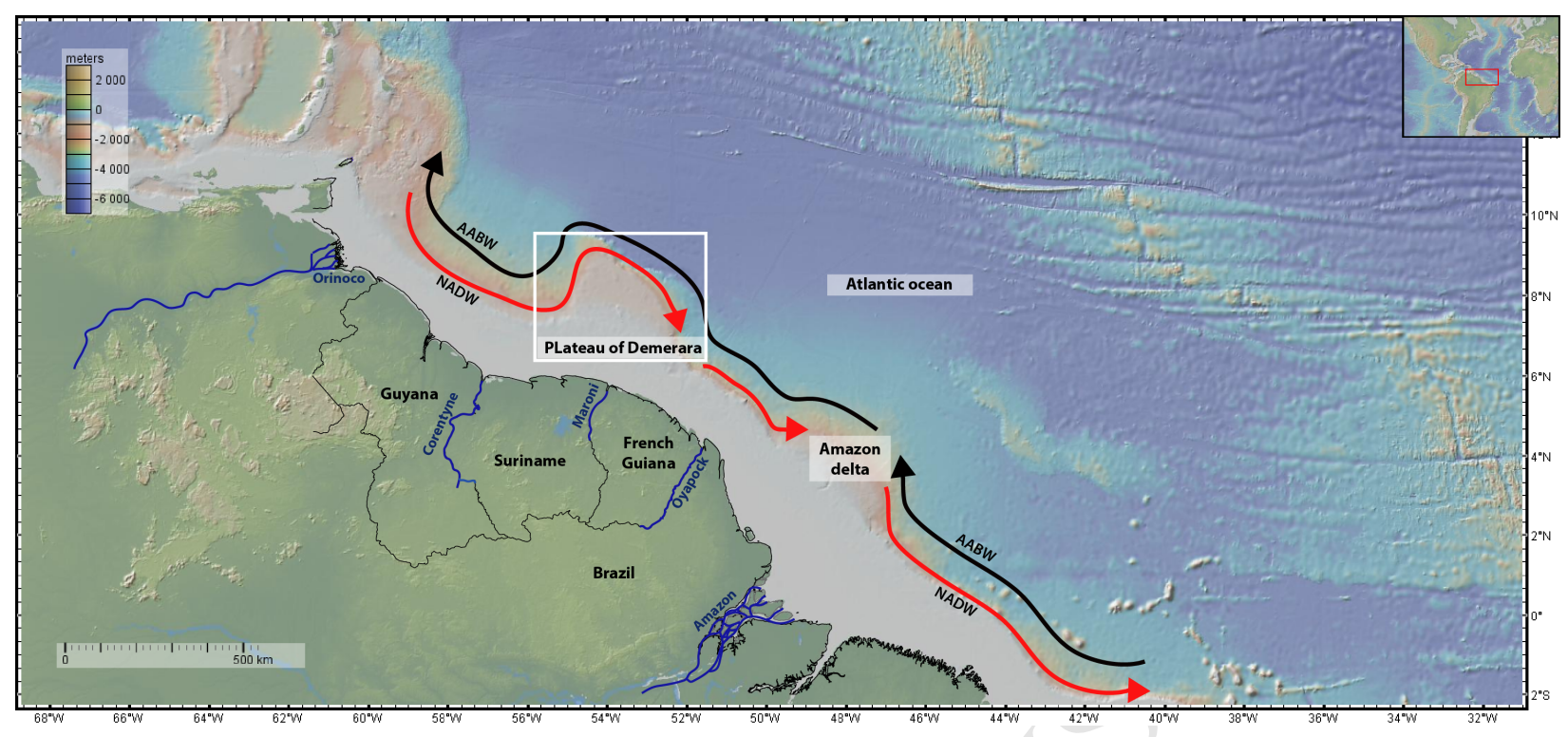




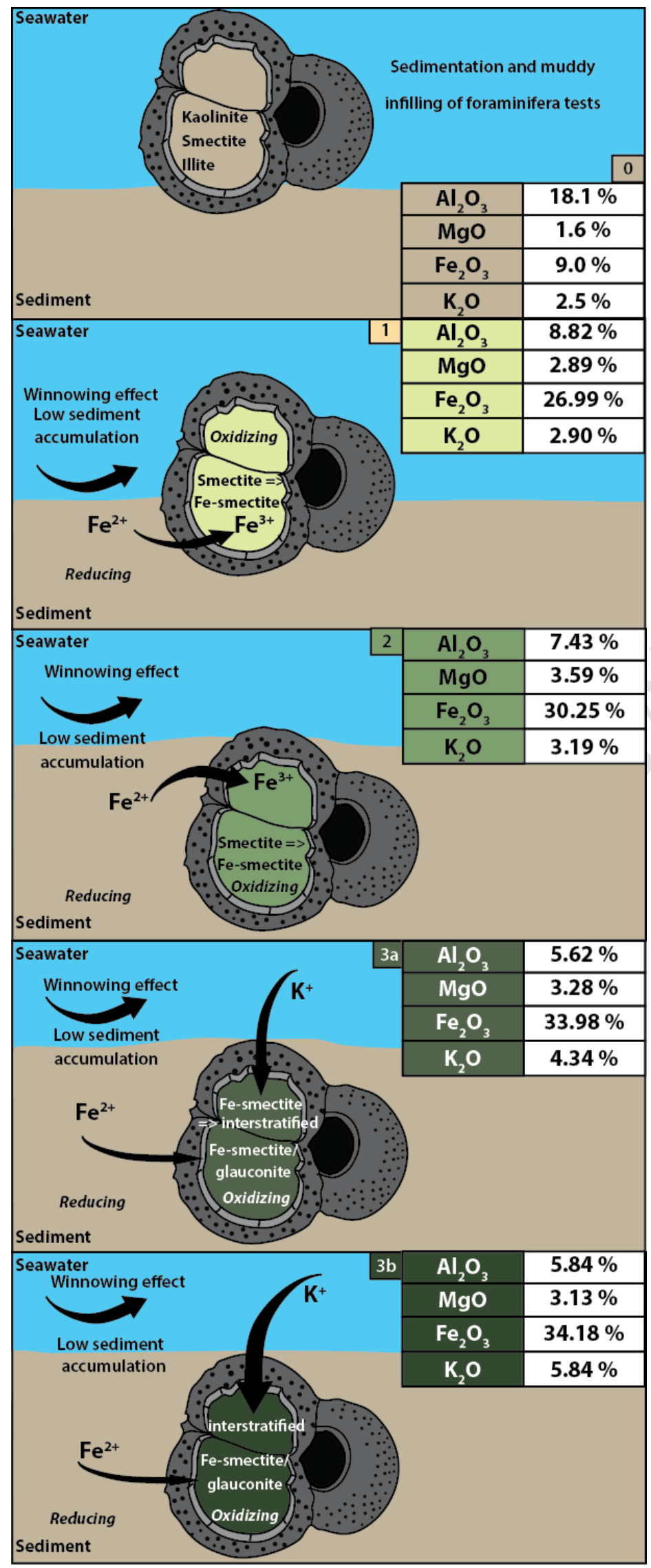




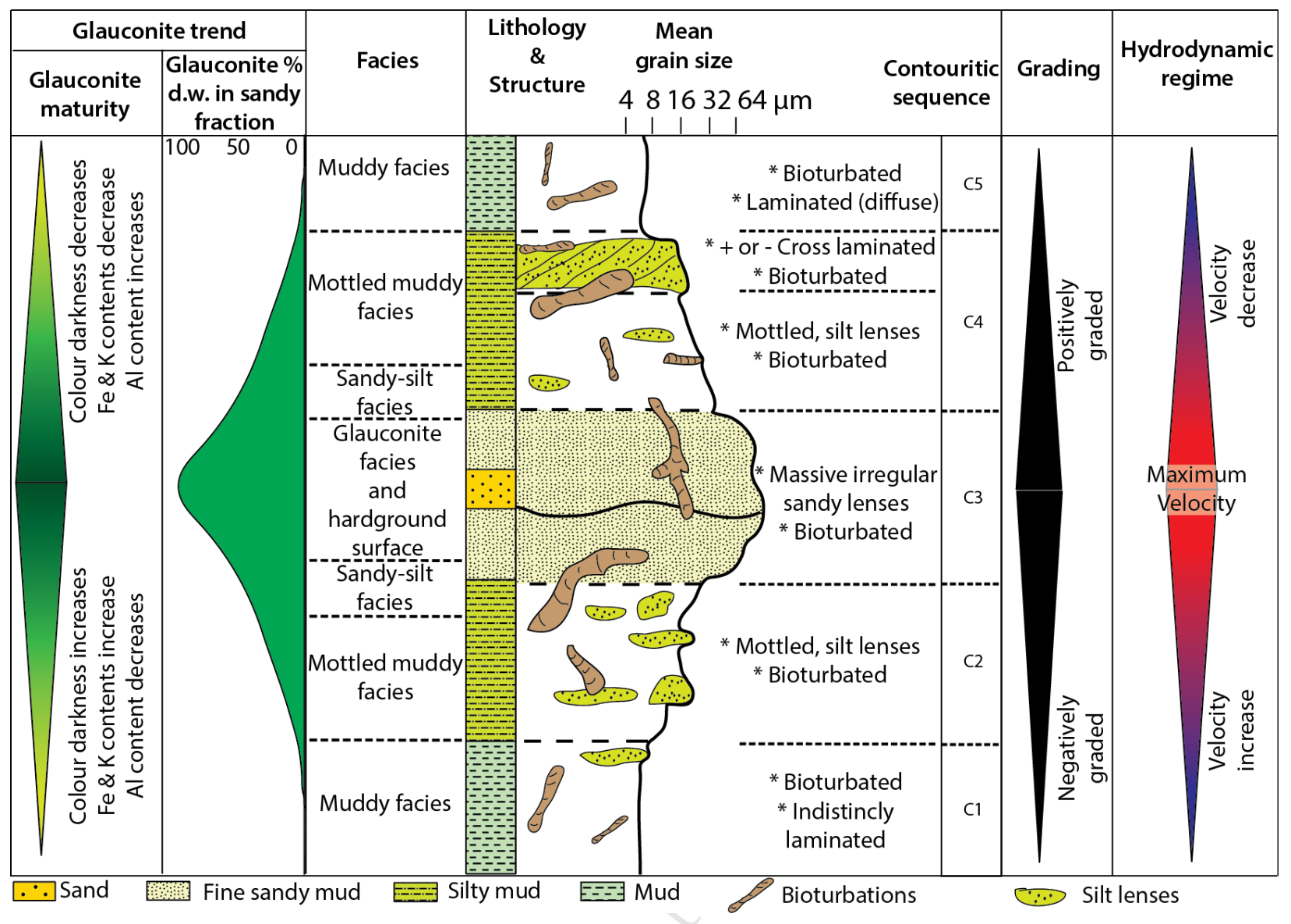




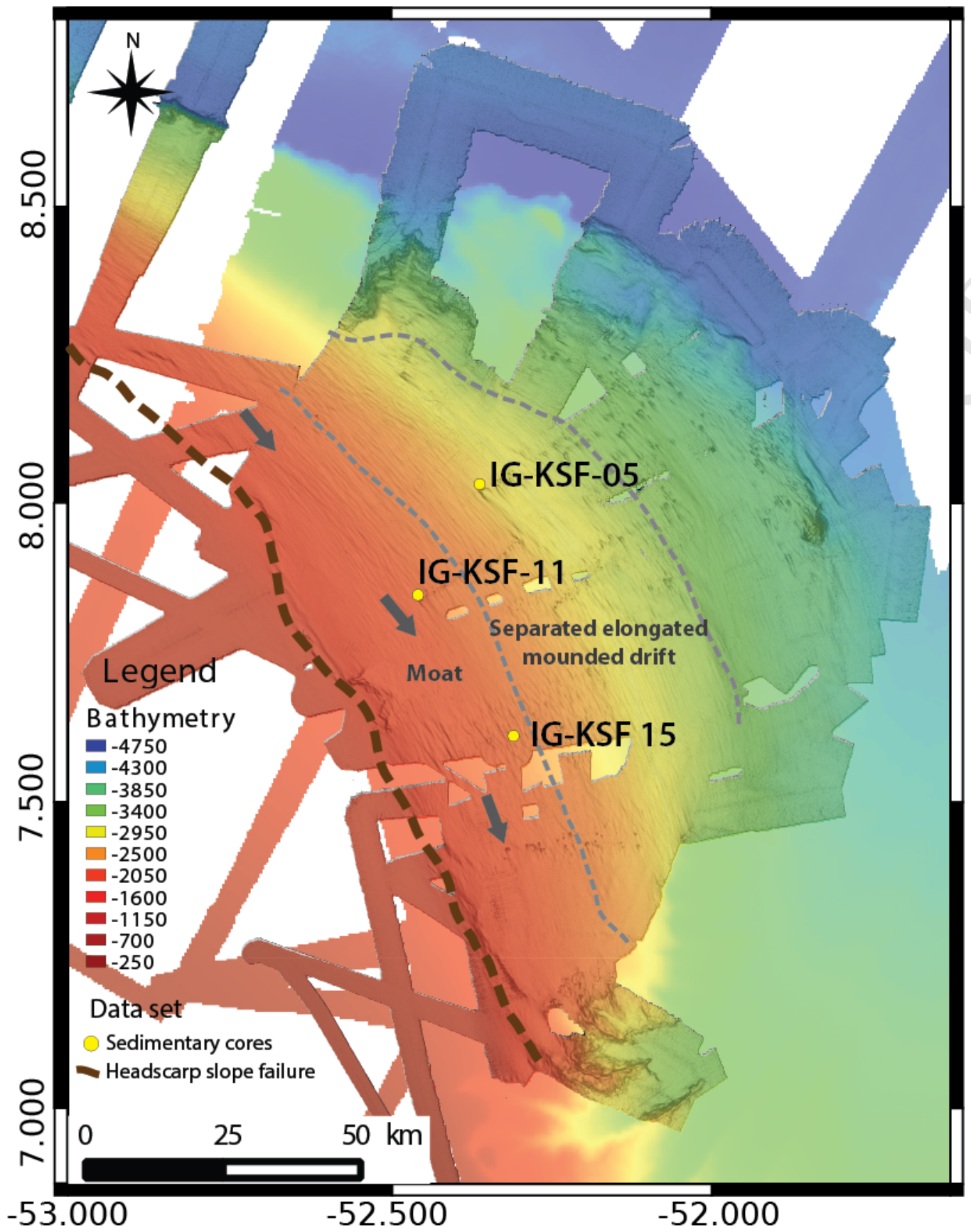




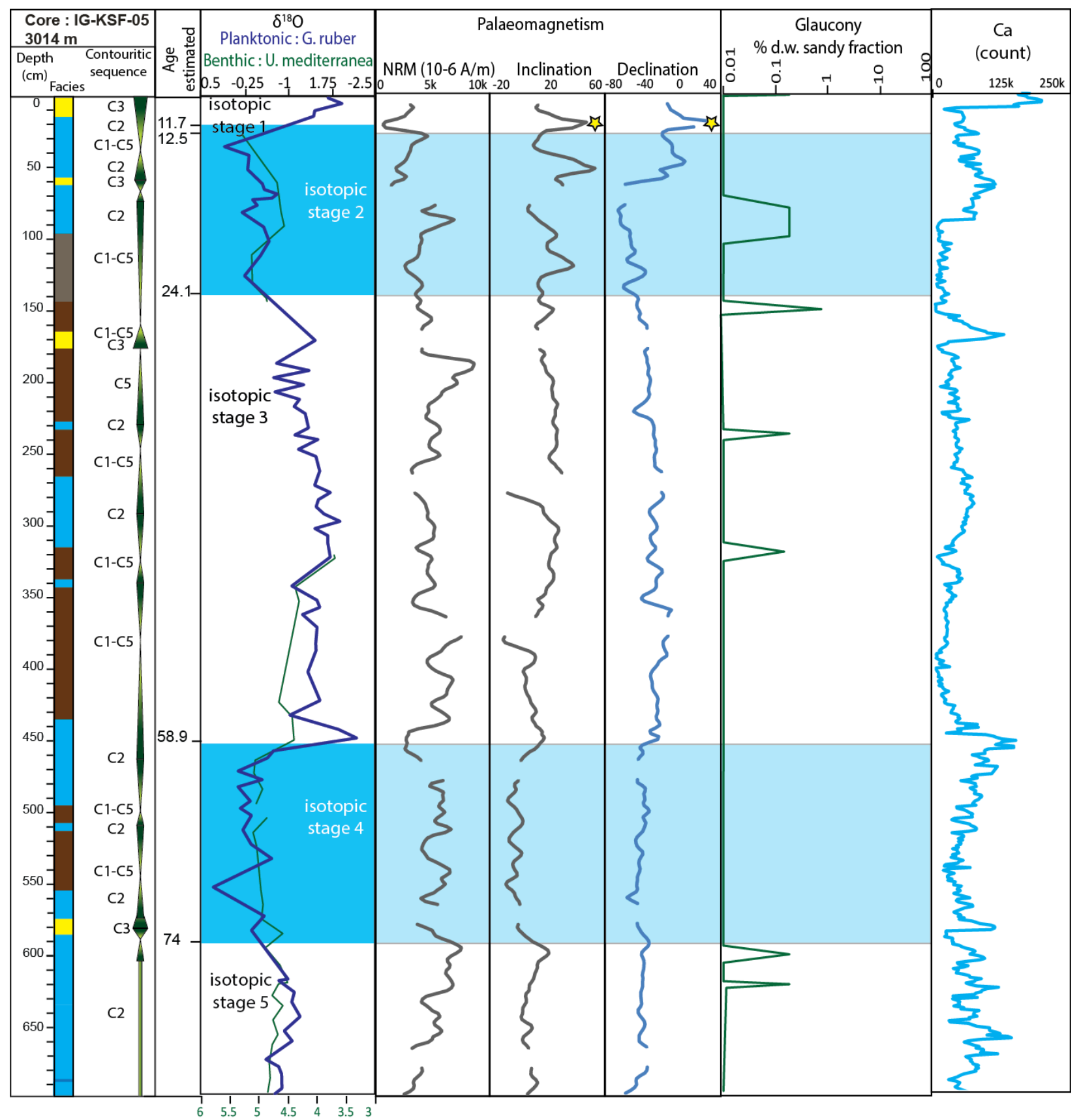




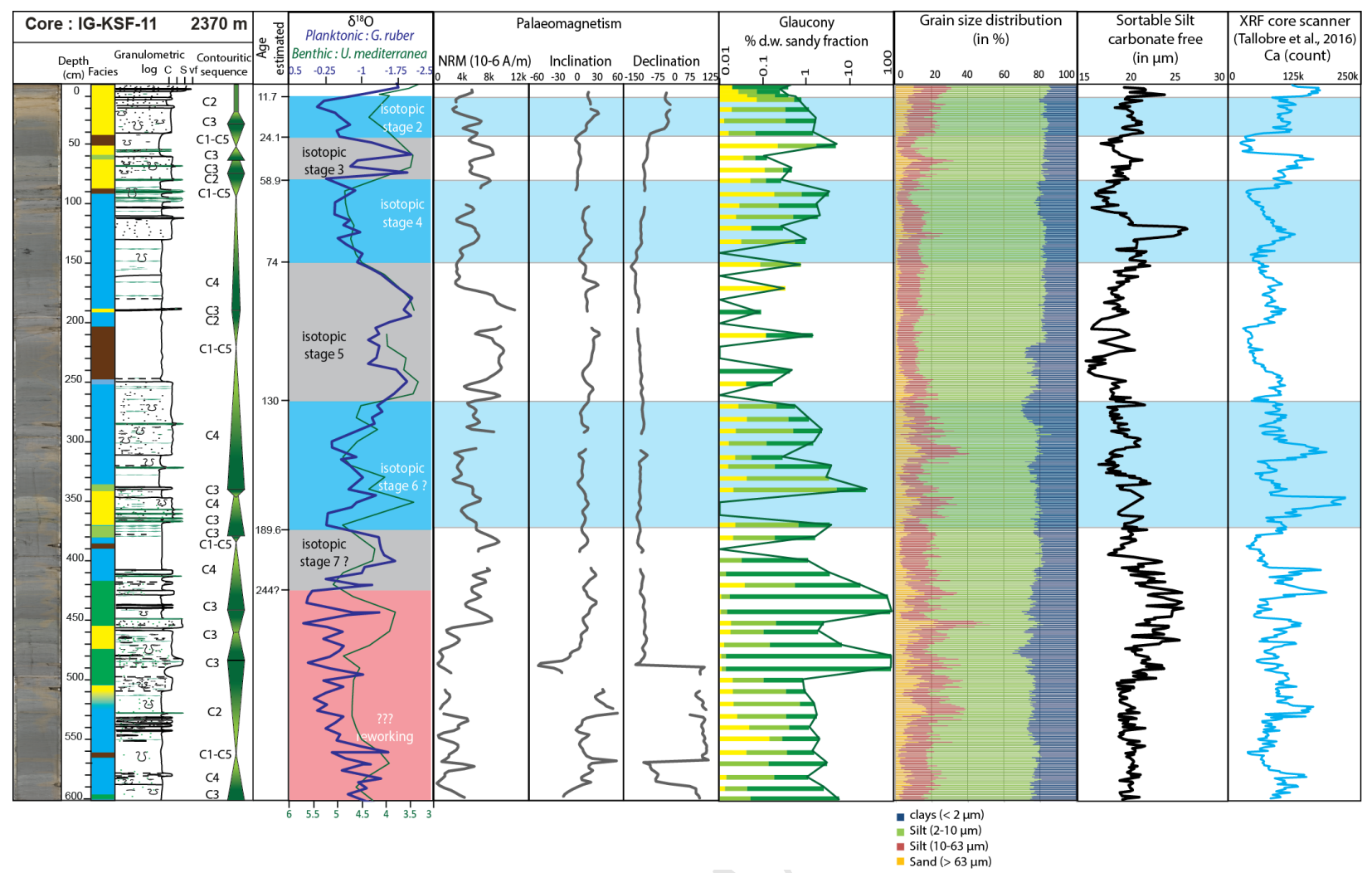




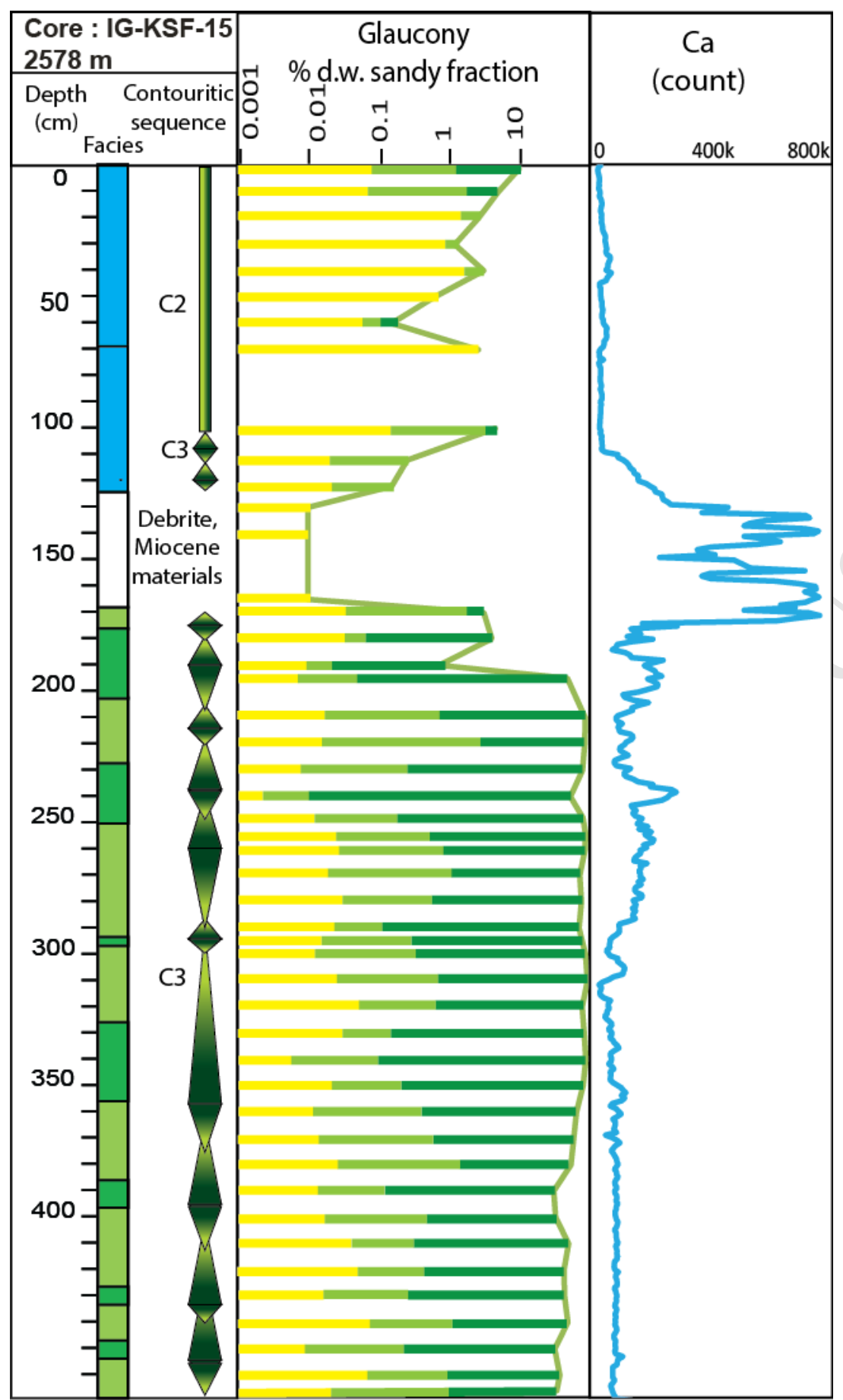




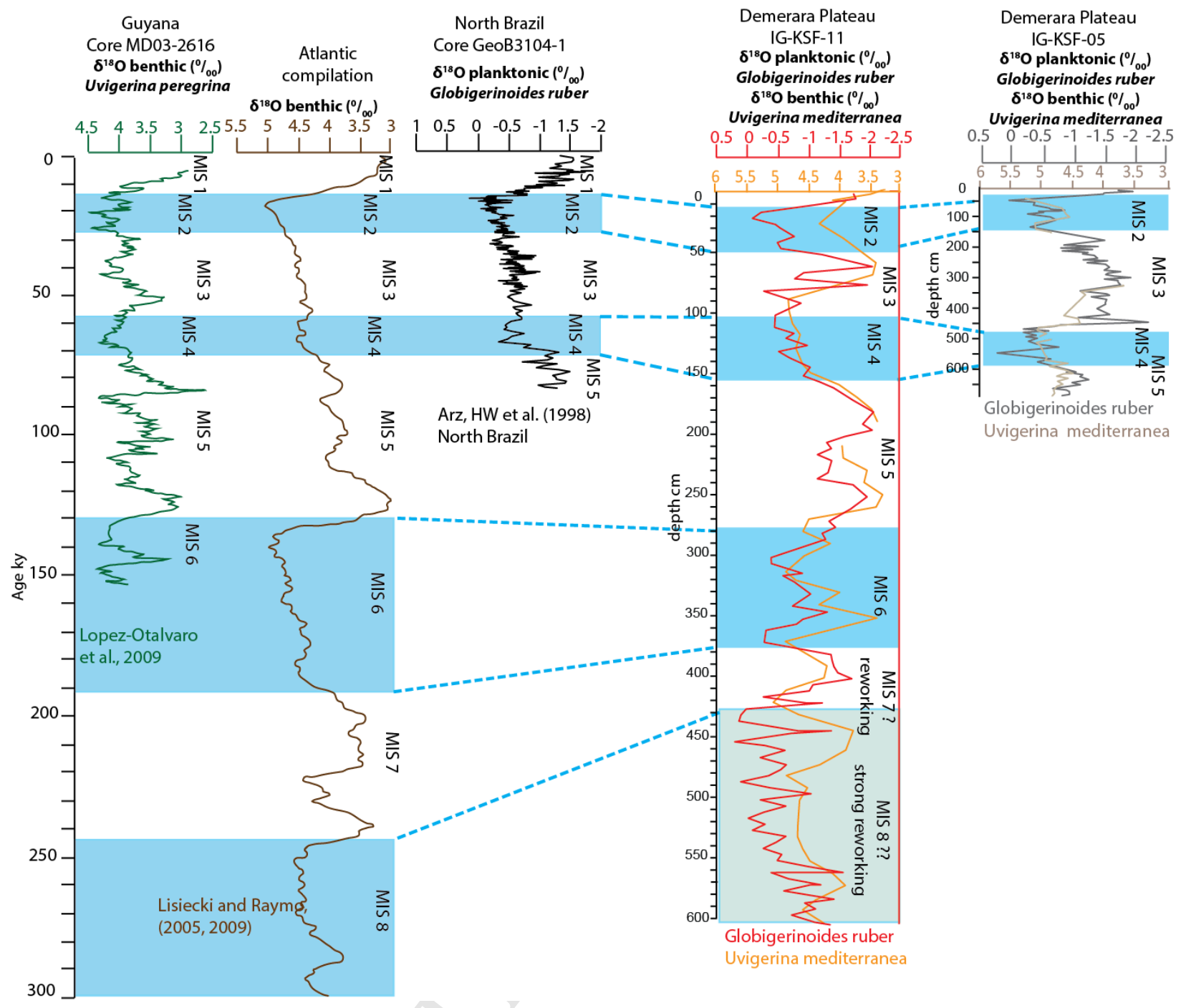



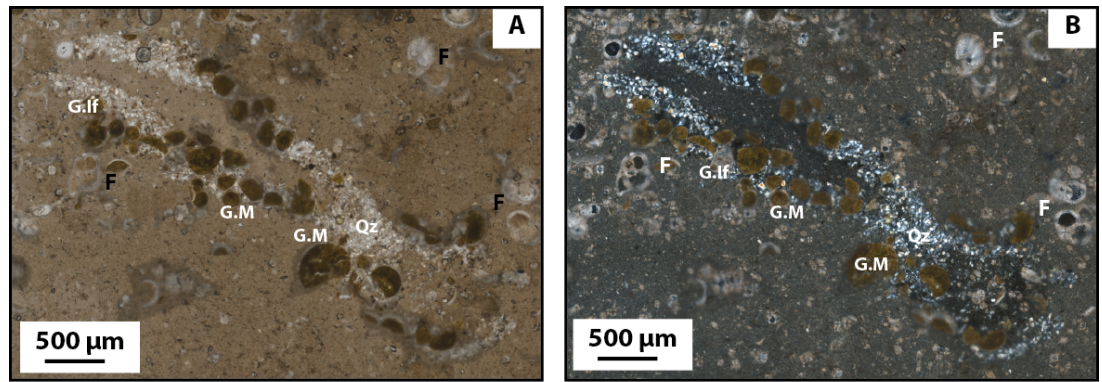

(A) in LPNA and (B) in LPA photos, illustration of bioturbation rich in glaucony and quartz in a facies F4.

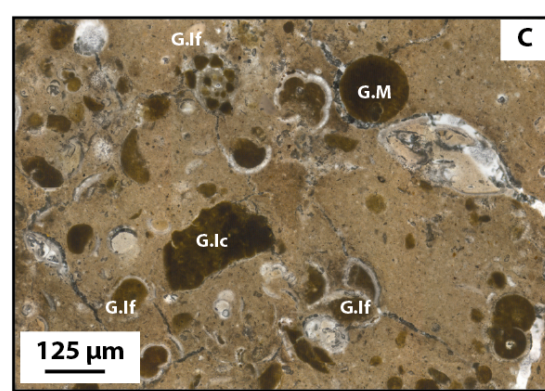

(C) LPNA photo, facies F2 with the different type of glaucony grains: inside foraminfera test, with foraminifera shape without test, and clast. Grains show a high degree of fracturing.

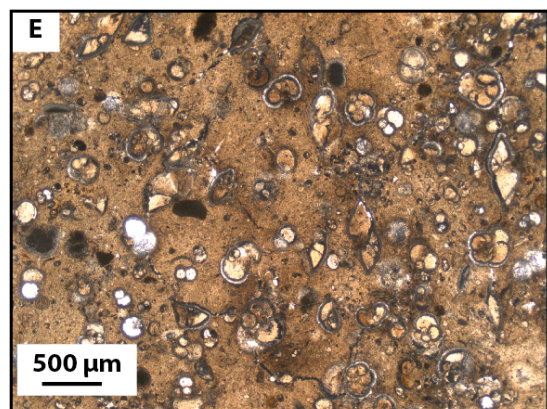

(E) LPNA photo of F3, sandy foraminifera with some glaucony grains (around $10 \%$ of glauco-

ny), low fracturing.

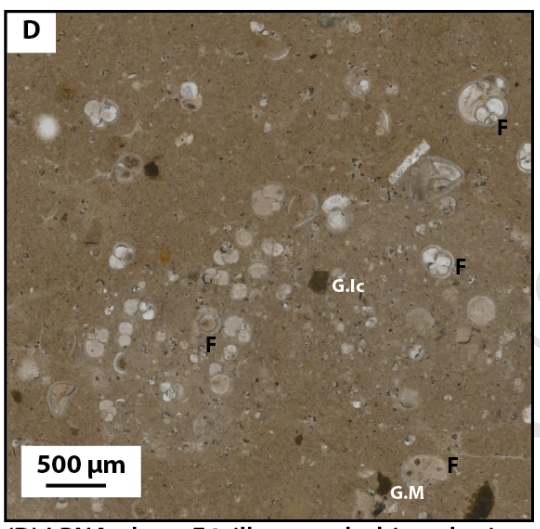

(D) LPNA photo F4, illustrated a bioturbation rich in foraminifera forming a lense in a fine mud with some grains.

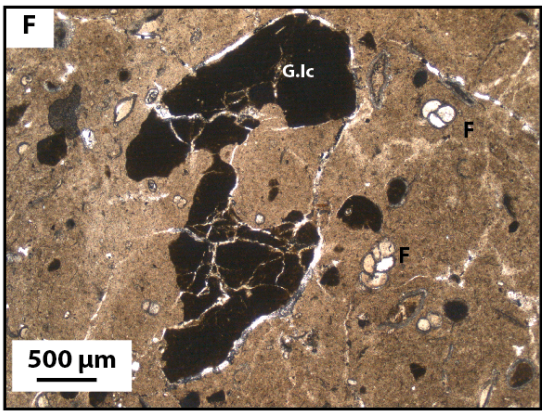

(F) LPNA photo of a glaucony clast probably coming from a glauconitic lithified surface. 

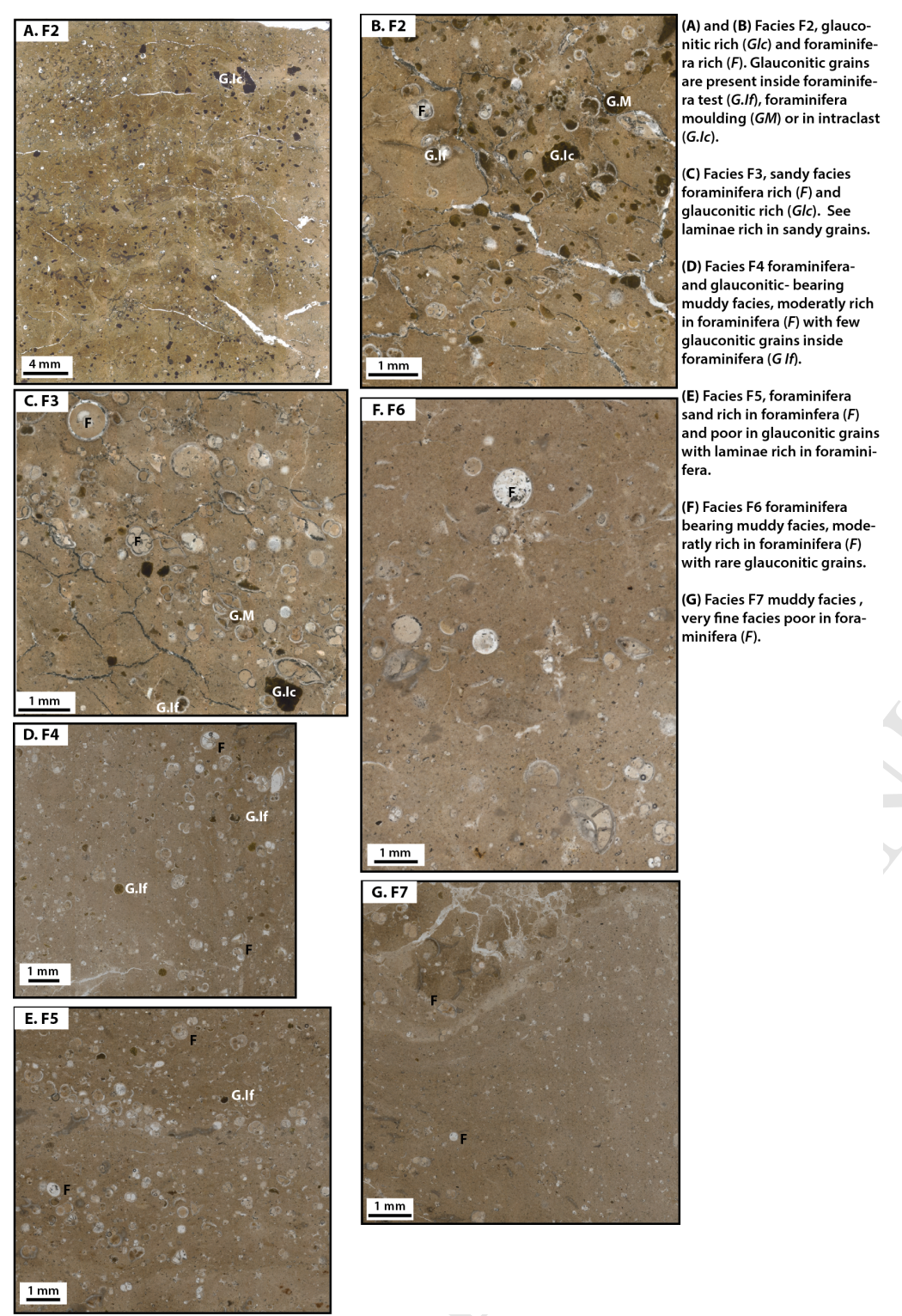


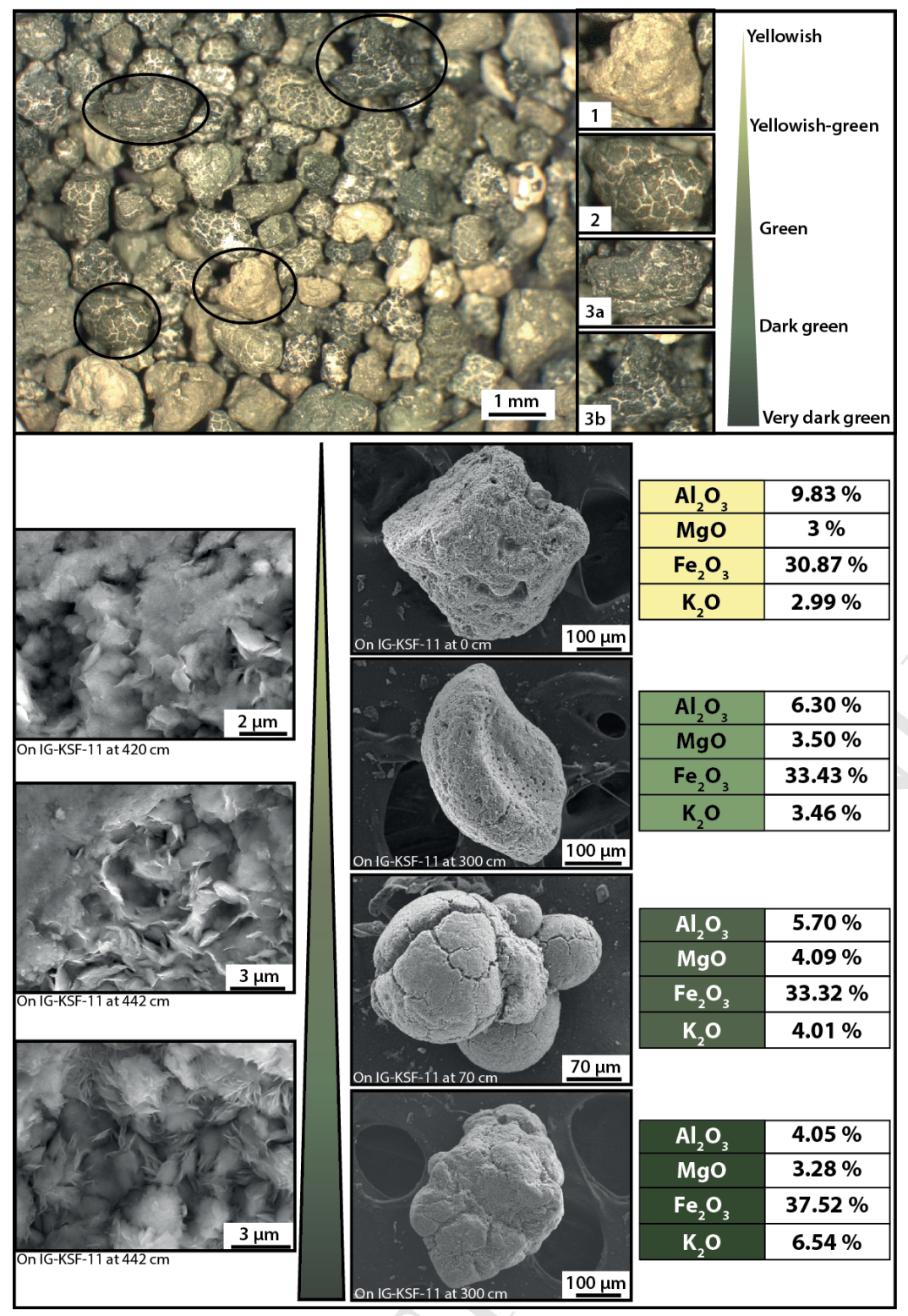

